\title{
Effect of short-term intermittent exposure to waterborne estradiol on the reproductive physiology of the round goby (Neogobius melanostomus)
}

\author{
Tatiana Guellard $^{1}(\mathbb{D}) \cdot$ Hanna Kalamarz-Kubiak ${ }^{1} \cdot$ Bartłomiej Arciszewski ${ }^{2}$
}

Received: 23 October 2019 / Accepted: 11 June 2020 / Published online: 22 June 2020

(C) The Author(s) 2020

\begin{abstract}
The objective of this study was to determine how the short-term exposure to a supraphysiological concentration of waterborne $17 \beta$-estradiol $\left(\mathrm{E}_{2}\right)$ influences on melatonin $(\mathrm{Mel})$ and thyroxine $\left(\mathrm{T}_{4}\right)$ concentrations in plasma and $\mathrm{E}_{2}$ and 11-ketotestosterone (11-KT) concentrations in plasma and gonads in both sexes of round goby (Neogobius melanostomus) during the pre-spawning, spawning, late spawning and non-spawning phases. The experimental protocol was based on short-term, repeated exposures of fish to a supraphysiological dose of waterborne $E_{2}$. Mel level was unchanged on exposure to $E_{2}$ during the investigated phases, and its role in determining a time frame for spawning in both sexes of round goby seems to be stable in those conditions. $\mathrm{T}_{4}$ and sex steroids $\left(E_{2}\right.$ and 11-KT) were sensitive to the exposure of $E_{2}$, and those changes influence gonads by accelerating oocyte development, ovulation and regression and inhibiting spermatogenesis in this species. The results demonstrate that the physiological responses of fish in all investigated phases were altered over a short window of exposure, indicating that short-term exposure to a supraphysiological dose of $E_{2}$ may impact fish in the wild. Furthermore, round goby can be recommended as a very suitable model for studying endocrine disruptors, which is sensitive to even short exposure to $E_{2}$.
\end{abstract}

Keywords Fish $\cdot$ Endocrine disruptions $\cdot 17 \beta$-estradiol $\cdot$ Melatonin $\cdot$ Thyroxine $\cdot$ Sex steroids $\cdot$ Reproductive cycle $\cdot$ Neogobius melanostomus

\section{Introduction}

There are several compounds entering an aquatic environment with municipal, pharmaceutical, agricultural and industrial sewage that can disturb the functioning of the endocrine system in fishes. These types of compounds belong to pollutants called endocrine disrupting compounds (EDCs). EDCs have

Responsible Editor: Philippe Garrigues

Electronic supplementary material The online version of this article (https://doi.org/10.1007/s11356-020-09702-3) contains supplementary material, which is available to authorized users.

Tatiana Guellard tguellard@iopan.gda.pl

1 Genetics and Marine Biotechnology Department, Institute of Oceanology, Polish Academy of Sciences, Sopot, Poland

2 Prof. Krzysztof Skóra Hel Marine Station, Institute of Oceanography, Faculty of Oceanography and Geography University of Gdańsk, Hel, Poland been defined as an exogenous substance or mixture of substances that change functions of the endocrine system and provoke adverse effects in an intact organism, its offspring and also subpopulations (Vos et al. 2000). EDCs mimic endogenous hormones and this way stimulate, block or disrupt their synthesis and metabolism leading to adverse developmental, reproductive, behavioural, neurological or immune effects in organisms (reviewed in Vethaak and Legler 2012). EDCs found in the aquatic environment can be of anthropogenic as well as natural origin. EDCs naturally occurring in aquatic ecosystems include estrogens, phytoestrogens, androgens or corticosteroids (Mills and Chichester 2005; Pait and Nelson 2002). Among the group of natural estrogenic EDCs are the steroid hormones, such as $17 \beta$-estradiol $\left(\mathrm{E}_{2}\right), 17 \alpha$ estradiol $\left(17 \alpha-E_{2}\right)$, estrone $\left(E_{1}\right)$ and estriol $\left(E_{3}\right)$, of which $E_{2}$ is the most potent compound (Adeel et al. 2017). Natural estrogens can act as endocrine disruptors when they are present in the environment in non-physiological concentrations. $\mathrm{E}_{2}$ found in aquatic environments comes mostly from domestic effluents but also from livestock waste and agriculture runoff (Desbrow et al. 1998; Ying et al. 2002; Shore and Shemesh 
2003). It has been identified as one of the main components responsible for estrogenicity of sewage treatment works' effluents (Desbrow et al. 1998). The presence of $E_{2}$ has been reported in waste and surface waters and marine sediments in many countries, with levels ranging from a few tenths of a nanogram per litre to a few thousands of a microgram per litre (Zhang et al. 2014; Rocha and Rocha 2015; Afifi et al. 2016; Pusceddu et al. 2019). The highest and supraphysiological concentrations of $\mathrm{E}_{2}$ have been detected in coastal zones exposed to discharges from large urban agglomerations and runoff from animal agricultural wastes (Elnwishy et al. 2012; Zhang et al. 2014; Afifi et al. 2016).

It is known that in an organism, $\mathrm{E}_{2}$ is synthesized in the gonads and brain and it is the most important oestrogen crucial in neural development, growth, sexual maturation, reproduction and sexual behaviour in both female and male vertebrates, including fish (Martyniuk et al. 2006; Plant and Zeleznik 2015). Estrogens may interact with the hypothalamus-pituitary-gonad (HPG) axis by modulating steroid synthesis, transport and catabolism, and by influencing the neuroendocrine system and the involved regulatory negative and positive feedback mechanisms. Most researchers were in favour of a concept of the negative feedback of estrogens on the pituitary through direct or indirect gonadotropin-releasing hormone (GnRH) inhibition in adult fish, and a positive feedback of estrogens only in early gonadal development (reviewed in Yaron and Levavi-Sivan 2011). Nevertheless, Olivereau and Olivereau (1979) have observed positive feedback of oestrogen on the pituitary gonadotrophs in adult females of the European silver eel (Anguilla anguilla). In the action of estradiol, both genome (nuclear) and non-genomic (extranuclear) mechanisms are exploited through nuclear or membrane receptors (Falkenstein et al. 2000; Nelson and Habibi 2013). Estrogens may also exert non-genomic action through a physico-chemical interaction with the plasma membrane at only micromolar concentrations without receptor involvement (Falkenstein et al. 2000).

Effects of exogenous $E_{2}$ have been extensively studied in fish; however, in the majority of these experiments, $E_{2}$ has been administrated during short or long constant water exposures or via ingestion, which does not reflect the influence of environmental conditions. Doses of $\mathrm{E}_{2}$ used in experiments ranged from a few nanograms in water exposure to several dozen of a milligramme per kilogramme of body weight in feed (reviewed in Piferrer 2001; Mills and Chichester 2005; Dietrich and Krieger 2009). In this study, the supraphysiological dose of $E_{2}$ was chosen on the basis of studies carried out by Hunter and Donaldson (1983), Goryczko et al. (1991), Kim et al. (1997) and DemskaZakęś (2005) as well as based on literature concerning the occurrence of high concentrations of $\mathrm{E}_{2}$ in coastal zones (Elnwishy et al. 2012; Zhang et al. 2014; Afifi et al. 2016). Overall, the effects of $E_{2}$ were noticed regardless of the length of exposure and the way the steroid was administered, and concerned, inter alia, altered plasma steroid, reduced egg or milt production, decrease in sexual behaviour and sexual characteristics in males, feminization and intersex gonads, and alterations in gonad structure (Miles-Richardson et al. 1999; Mills and Chichester 2005; Dietrich and Krieger 2009). In the natural environment, fish are exposed transiently to fluctuating levels of contaminants due to their natural diurnal and seasonal migrations linked with reproduction and also changes of feeding grounds, and due to irregular inputs of contaminants into the environment (National Research Council 1993). Only a few studies investigated intermittent waterborne $\mathrm{E}_{2}$ exposure (Panter et al. 2000; Martinović et al. 2008; Hyndman et al. 2010). In most studies, the applied procedures did not reflect environmental conditions. However, Panter et al. (2000) demonstrated that the response of intermittently exposed fish is more evident than that of fish exposed continuously. Therefore, this study is based on several short-term, repeated exposures of fish to a supraphysiological concentration of waterborne $E_{2}$ using a similar protocol scheme to that used by Panter et al. (2000). The method of $E_{2}$ administration (water baths) used in this study was selected according to Hunter and Donaldson (1983) and Goryczko et al. (1991).

The round goby (Neogobius melanostomus) is a batch spawning fish originating from the Ponto-Caspian basins which has successfully invaded much of the Baltic Sea and Great Lakes of North America (Kornis et al. 2012). The first occurrence of this species in the Baltic Sea was noticed in the Gulf of Gdańsk in 1990 (Skóra and Stolarski 1993). Since then, $N$. melanostomus has become one of the most abundant species in the western part of the Gulf of Gdańsk, successfully colonizing other regions of the Baltic Sea (Sapota 2012). The success of $N$. melanostomus invasion in the Baltic Sea is due to its aggressive and territorial behaviour, high adaptation to diverse environmental factors, varied diet and reproductive strategy (Kornis et al. 2012; Ojaveer et al. 2015). $N$. melanostomus was chosen as a biological model to investigate the $E_{2}$ effects because of its sensitivity to endocrine disruption and greater predisposition to develop gonadal intersex and feminization of secondary sexual characteristics than other fish species (Bowley 2010; Guellard et al. 2015). Moreover, distribution and a large population of this invasive species in the Gulf of Gdańsk allow comprehensive monitoring without disrupting the existence of native fish populations. $N$. melanostomus is also relatively easy to catch because it is a bottom-dwelling fish occupying shallow inshore waters where it can be obtained in large numbers. To the authors' knowledge, there is only one study investigating the influence of intraperitoneal injections of $\mathrm{E}_{2}$ on $N$. melanostomus, which concerned the response of vitellogenins (Vtgs) gene expression (Bowley et al. 2010). There is no complex study evaluating the effects of exogenous $\mathrm{E}_{2}$ on the reproductive physiology including crucial hormones such as melatonin (Mel), 
thyroxine $\left(\mathrm{T}_{4}\right)$ and gonadal sex steroids in different phases of the reproductive cycle in any fish species.

The effect of Mel on estrogens was widely investigated in higher vertebrates as well as in fish because Mel synchronizes the stage of different biological rhythms, physiological processes and behavioural changes involved in reproduction (Maitra and Hasan 2016; Falcón et al. 2010). The opposite effect is not frequently studied in vertebrates except mammals. Estradiol's effect on Mel was explored with respect to carcinogenesis and menopause, and the post-menopausal period in humans (Toffol et al. 2014; Reiter et al. 2017). $\mathrm{T}_{4}$ is one of the primary hormones produced by the thyroid gland and plays a major role in the regulation of metabolism, growth and development, sexual maturation and breeding cycle in all vertebrates, including fish (Leatherland 1994; Power et al. 2001). Exogenous $E_{2}$ has been shown to alter plasma $T_{4}$ levels in fish and in this way affecting reproductive processes (Leatherland 1985; Bandyopadhyay et al. 1991; Chakraborti and Bhattacharya 1984). However, most of the studies have used an injection of $\mathrm{E}_{2}$, which does not reflect environmental contaminations. $\mathrm{E}_{2}$ and $11-\mathrm{KT}$ are the most potent steroids playing a crucial role in fish reproduction. $\mathrm{E}_{2}$ is a major female hormone, responsible for the development of oocytes by promoting hepatic Vtg synthesis (Lubzens et al. 2010). In males, $\mathrm{E}_{2}$ influences spermatogenesis, particularly spermatogonial proliferation (Schulz et al. 2010). 11-KT is crucial for stimulation of spermatogenesis and growth and development of testes (Borg 1994; Schulz et al. 2010). This male hormone is also present in low concentrations in females and it has been shown to contribute to oocyte growth (Rohr et al. 2001; Lokman et al. 2007). The effects of exogenous estrogens have been extensively studied in fish, while studies on the effect on endogenous sex steroids were less frequent. What is more, most of these studies were carried out on male or juvenile individuals (reviewed in Mills and Chichester 2005; Dietrich and Krieger 2009).

The aim of this study was to determine how the short-term, intermittent exposure to exogenous, waterborne $\mathrm{E}_{2}$, mimicking environmental conditions, affects $\mathrm{Mel}$ and $\mathrm{T}_{4}$ concentrations in plasma and $\mathrm{E}_{2}$ and 11-KT concentrations in plasma and gonads in mature females and males of $N$. melanostomus in four phases of the reproductive cycle defined as the prespawning, spawning, late spawning and non-spawning phases.

\section{Materials and methods}

\section{Fish and experimental design}

Adult females and males $N$. melanostomus $(n=336)$ were caught using fyke nets in the vicinity of Hel Harbour $\left(54^{\circ}\right.$ $36^{\prime} 04.17^{\prime \prime} \mathrm{N}, 18^{\circ} 47^{\prime} 56.06^{\prime \prime} \mathrm{E}$ ) (Gulf of Gdańsk, southern
Baltic Sea) in March, April, July and October. Captured fish were transferred to the Marine Station (Institute of Oceanography, University of Gdańsk, Poland) in Hel where they were sexed by examination of the urogenital papilla. In every studied phase, they were divided into four groups, each consisting of 21 fish of both sexes (7 females and 14 males). Each group of fish was kept at natural photoperiod and temperature (Table 1) in a $2640 \mathrm{~L}$ outdoor tank with a flowthrough system to provide water from the Gulf of Gdańsk $(\sim 7 \mathrm{psu})$. In addition, hideouts made from PVC pipes were placed in each tank to mimic natural living conditions of $N$. melanostomus. Fish were fed once a day with fresh fish meat (herring), frozen mussels or shrimps. The temperature and salinity were monitored and measured using a portable meter CC-401 (ELMETRON, Zabrze, Poland) every day at noon. Before an experiment, fish were acclimatized to the tank conditions for two weeks.

After acclimatization, the following four experimental groups were established (Fig. 1):

$\mathrm{C} 1$ - control stationary group kept in outdoor seawater tank that was not subjected to any kind of transfer or bath;

C2 - control group transferred from its seawater tank to the seawater bath to investigate a possible influence of experimental procedure;

C3 - control group transferred and bathed in the seawater supplemented with ethanol that was used as a solvent for $\mathrm{E}_{2}$;

$\mathrm{E}_{2}$ - exposed group transferred and bathed in the seawater supplemented with $\mathrm{E}_{2}$ solution.

Groups C2, C3 and $E_{2}$ were subjected to four series of short-term baths during the 27 days of the experiment (Fig. 1). The three-day series of baths were carried out in five-day intervals. Each bath lasted $2 \mathrm{~h}$ from 11 AM to $1 \mathrm{PM}$. Fish from groups $\mathrm{C} 2, \mathrm{C} 3$ and $\mathrm{E}_{2}$ were transferred in containers from outdoor tanks to indoor $500 \mathrm{~L}$ glass aquaria with aerated seawater. Each group was maintained in a separate aerated aquarium with the same volume of seawater, with or without supplements. The $\mathrm{E}_{2}$ solution was prepared before each bath by dissolving $0.05 \mathrm{~g} \mathrm{E}_{2}$ (MERCK KGaA, Germany) in ethanol (J.T. Baker, Phillipsburg, USA). Nominal $\mathrm{E}_{2}$ and ethanol concentrations in aquaria water were $200 \mu \mathrm{g} / \mathrm{L}$ and $0.02 \%$, respectively. After each two-hour bath, fish were transferred back to their outdoor tanks in containers with aerated

Table 1 Average day length, water temperature and salinity $( \pm$ SEM $)$ in tanks and aquaria during investigated phases

\begin{tabular}{llll}
\hline Phase & Day length $(\mathrm{h})$ & Water temperature $\left({ }^{\circ} \mathrm{C}\right)$ & Salinity $(\mathrm{psu})$ \\
\hline Pre-spawning & 13 & $4.8 \pm 0.5$ & $7.8 \pm 0.1$ \\
Spawning & 15 & $11.5 \pm 2.5$ & $6.7 \pm 0.3$ \\
Late spawning & 14 & $19.6 \pm 1.2$ & $6.7 \pm 0.3$ \\
Non-spawning & 10 & $11.0 \pm 1.3$ & $7.0 \pm 0.1$ \\
\hline
\end{tabular}


Fig. 1 Scheme of single bath series exposures. Acclimated individuals of $N$. melanostomus were divided into the following four groups: $\mathrm{C} 1-$ control stationary group; $\mathrm{C} 2$ - control group transferred from its seawater tank to the seawater bath; C3 - control group transferred and bathed in the seawater supplemented with ethanol; $\mathrm{E}_{2}$ - group transferred and bathed in the seawater supplemented with $\mathrm{E}_{2}$ solution. Groups $\mathrm{C} 2, \mathrm{C} 3$ and $\mathrm{E}_{2}$ were subjected to four series of shortterm baths with 5-day intervals for 27 days of the experiment. Each series consisted of 2-h baths repeated for three consecutive days. Each group of fish (C2, C3 and $\mathrm{E}_{2}$ ) was transferred from outdoor tanks into the appropriate indoor glass aquaria using containers with aerated water
TANKS

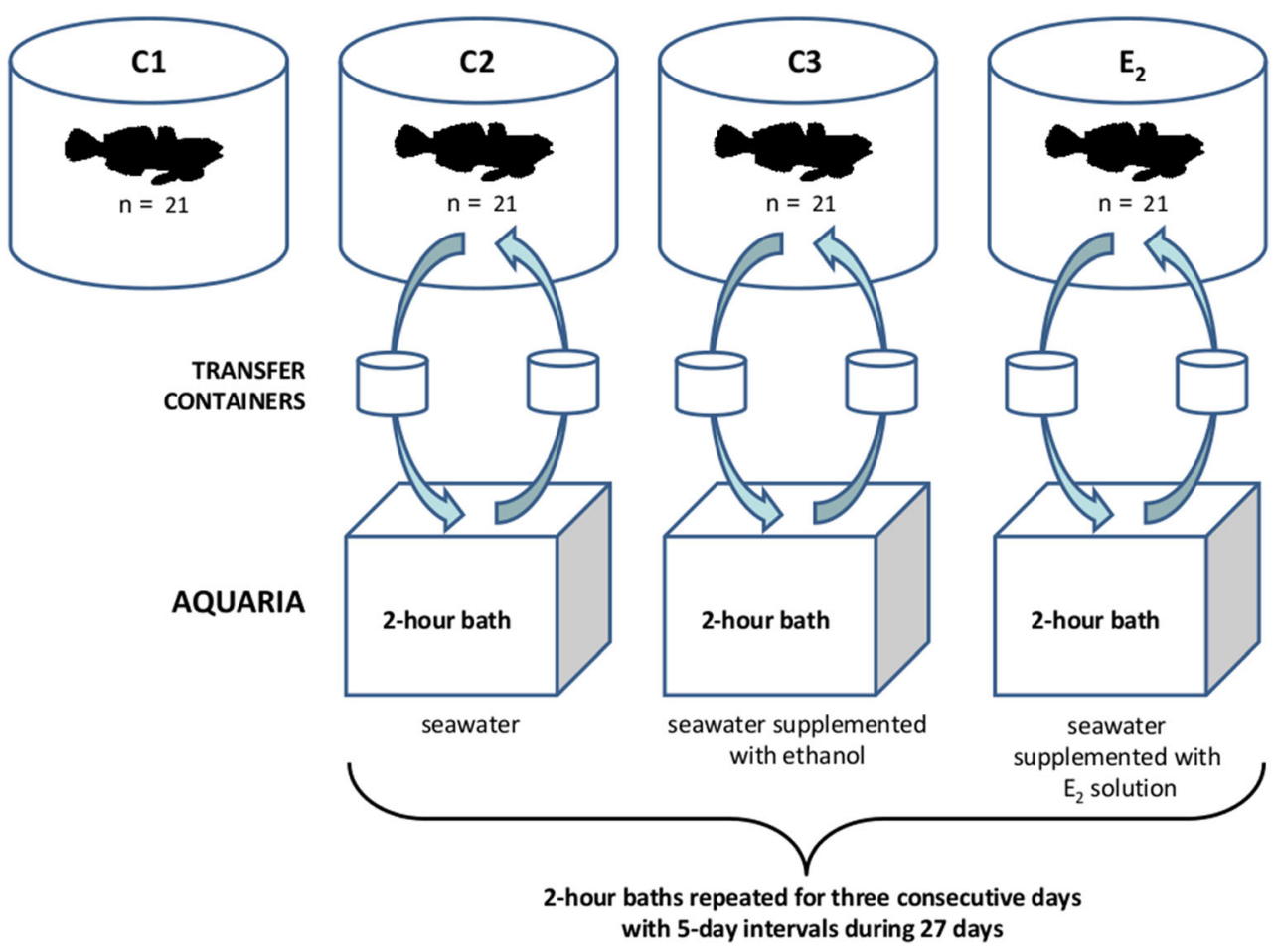

seawater. At the beginning and at the end of each bath, water parameters (temperature, salinity, dissolved oxygen, $\mathrm{pH}$, nitrate and nitrite, phosphate and ammonium/ammonia) were measured in each tank and aquarium and water samples $(10 \mathrm{~mL})$ from each aquarium were collected and stored at $-70{ }^{\circ} \mathrm{C}$ until further $\mathrm{E}_{2}$ analysis. Temperature and salinity were measured using a portable meter Elmetron CC-401 (ELMETRON, Zabrze, Poland) while the other parameters ( $\mathrm{pH}$, dissolved oxygen, nitrate, nitrite, phosphate, ammonium and ammonia) were determined using water tests (Tetra, Spectrum Brands Company, Melle, Germany).

\section{Tissue sampling}

At the time of sampling, fish were anaesthetized in MS-222 (tricaine methanesulfonate) water buffered solution $(0.1 \mathrm{~g} / \mathrm{L})$ (Sigma-Aldrich, Saint Louis, USA). Sampling took place between 10 AM and 2 PM. Each fish was measured (to the nearest $0.1 \mathrm{~cm}$ ) and weighed (to the nearest $0.01 \mathrm{~g}$ ). Blood samples were collected by cardiac puncture, using a heparinized syringe. The plasma samples were centrifuged at $3000 \mathrm{~g}$ for $10 \mathrm{~min}$ at $4{ }^{\circ} \mathrm{C}$ and frozen at $-70{ }^{\circ} \mathrm{C}$ until analyses. After blood sampling, fish were euthanized by transection of the spinal cord. Collected gonads and liver of each fish were weighed to the nearest $0.01 \mathrm{~g}$ for establishing of the gonadosomatic index (GSI) and hepatosomatic index (HSI). GSI and HSI of $N$. melanostomus females and males were determined by the following equations: GSI = gonad weight / body weight $\times 100$; HSI = liver weight $/$ body weight $\times 100$. Then, one gonad of each was frozen at $70{ }^{\circ} \mathrm{C}$ and kept until steroid analysis while the second one was preserved in $4 \%$ buffered formalin $(\mathrm{POCH}$, Gliwice, Poland) for histology analysis.

\section{Hormone measurement}

\section{Plasma melatonin analysis}

Plasma Mel was assayed using a total melatonin radioimmunoassay (RIA) kit (RE29301, IBL International, Hamburg, Germany), with preceding extraction procedure according to the method presented by Kulczykowska et al. (2007) and modified by Guellard et al. (2019). The solid-phase extraction was carried out on Octadecyl C18 Speedisk Column, $10 \mu \mathrm{m}$ (J.T. Baker, Phillipsburg, USA). Mel labelled with iodine-125 $\left({ }^{125} \mathrm{I}\right)$ was used as a tracer for this analysis. All samples in duplicate were counted for $1 \mathrm{~min}$ in a Wallac Wizard 1470 gamma counter (Perkin Elmer Life Science, Waltham, USA). The detection limit was $3.0 \mathrm{pg} / \mathrm{mL}$ of plasma. The intra-assay coefficients of variation were $6.5 \%$. The inter-assay variation was not determined because all samples were measured in the same assay.

\section{Plasma thyroxine analysis}

Plasma $\mathrm{T}_{4}$ was measured by a total thyroxine RIA kit (OCPG07-T4, Cisbio Bioassays, Codolet, France) without preceding extraction procedure according to the method 
presented by Kulczykowska et al. (2007). The $\mathrm{T}_{4}$ labelled with ${ }^{125} \mathrm{I}$ was used as a tracer for RIA. All samples were assayed in duplicate and counted for $1 \mathrm{~min}$ in a Wallac Wizard 1470 gamma counter (Perkin Elmer Life Science, Waltham, USA). The detection limit was $1.1 \mathrm{ng} / \mathrm{mL}$ of plasma. The intra-assay coefficients of variation were $5.6 \%$. The inter-assay variation was not determined because all samples were measured in the same assay.

\section{Steroids' analysis in plasma}

Plasma $\mathrm{E}_{2}$ was measured using RIA kit (ESTR-CTRIA, Cisbio Bioassays, Codolet, France) without preceding extraction procedure according to the manufacturer's protocol validated in our laboratory (Kalamarz-Kubiak et al. 2017; Guellard et al. 2019). $E_{2}$ iodinated with ${ }^{125} \mathrm{I}$ was used as a tracer. The radioactivity in each tube was measured for 1 min in a Wallac Wizard 1470 gamma counter (Perkin Elmer Life Science, Waltham, USA). The detection limit of the assay was $4.25 \mathrm{pg} / \mathrm{mL}$. The intra-assay coefficients of variation were $2.1 \%$. The inter-assay variation was not determined because all samples were measured in the same assay.

Plasma 11-KT was determined using a competitive enzyme immunoassay (EIA) kit (582751, Cayman Chemical, Ann Arbor, USA) with preceeding extraction procedure according to the method described by Sokołowska et al. (2013) and modified by Guellard et al. (2019). The plate was read at $412 \mathrm{~nm}$ using the absorbance microplate reader (Sunrise ${ }^{\mathrm{TM}}$, Tecan, Männedorf, Switzerland). All samples were assayed in duplicate. The detection limit of the assay was $0.7 \mathrm{pg} / \mathrm{mL}$. The intra-assay coefficients of variation were $0.6 \%$. The interassay variation was not determined because all samples were measured in the same assay.

\section{Steroids' analysis in gonads}

Each collected ovary and testis was sonicated in $0.5 \mathrm{~mL}$ of phosphate buffer (0.05 M, pH 7.4) supplemented with sodium azide $(0.0015 \mathrm{M}$; Sigma-Aldrich, Saint Louis, USA) using an ultrasonic homogeniser $\left(\right.$ Microson $^{\mathrm{TM}} \mathrm{XL}$ 2000, Misonix, Farmingdale, USA). Sonicated samples were centrifuged at $20,000 \mathrm{~g}$ for $20 \mathrm{~min}$ at $4{ }^{\circ} \mathrm{C}$. The supernatants were stored at $-70{ }^{\circ} \mathrm{C}$ prior to the analysis of $\mathrm{E}_{2}$ and 11-KT levels.

The $E_{2}$ concentrations in extracts from ovaries and testes were determined using RIA kit (ESTR-CTRIA, Cisbio Bioassays, Codolet, France) according to the method previously presented by Kulczykowska et al. (2015). Gonad supernatants $(200 \mu \mathrm{L})$ were extracted with $1.6 \mathrm{~mL}$ of diethyl ether (Fisher Scientific, Loughborough, UK) according to the modified method by Mori and Kano (1984). The recovery rate of the extraction was between 86 and 109\%. The detection limit of RIA was $4.25 \mathrm{pg} / \mathrm{mL}$. The intra-assay coefficients of variation were $6.5 \%$. The inter-assay variation was not determined because all samples were measured in the same assay.

The 11-KT concentrations in extracts from ovaries and testes were measured using EIA kit (582751, Cayman Chemical, Ann Arbor, USA) with the extraction procedure previously described by Kulczykowska et al. (2015). The recovery of extraction was between 98 and $115 \%$. The detection limit of EIA was $1.09 \mathrm{pg} / \mathrm{mL}$. The intra-assay coefficients of variation were $0.8 \%$. The inter-assay variation was not determined because all samples were measured in the same assay.

\section{$17 \beta$-Estradiol analysis in water}

Water samples were extracted according to the methods described by Kramer et al. (1998) and Fuzzen et al. (2011) with slight modification. Samples collected from the experimental tank $(5 \mathrm{~mL})$ were extracted with $3 \mathrm{~mL}$ diethyl ether (Fisher Scientific, Loughborough, UK). Samples were vortexed for $30 \mathrm{~s}$ and then held at $-20^{\circ} \mathrm{C}$ for $10 \mathrm{~min}$ to separate the layers. The diethyl ether layer was decanted into a glass tube and dried under a gentle stream of air. This extraction procedure was performed three times. Dried extracts were stored at $-20{ }^{\circ} \mathrm{C}$ until RIA analysis. The recovery rate of the extraction was between 89 and $105 \%$. The $\mathrm{E}_{2}$ concentration in water samples was determined using an RIA kit (ESTR-CTRIA, Cisbio Bioassays, Codolet, France). Before measurements, extracts were reconstituted in $3 \mathrm{~mL}$ of phosphate buffer $(0.05 \mathrm{M}$, $\mathrm{pH}$ 7.4) supplemented with sodium azide (0.0015 M; SigmaAldrich, Saint Louis, USA) and samples of $100 \mu \mathrm{L}$ were taken for RIA analysis. A standard curve was prepared using six standard dilutions of $17,105,320,880,1910$ and $4800 \mathrm{pg} /$ $\mathrm{mL}$. The assay was conducted in RIA tubes according to the kit manufacturer's instructions. The tubes were vortexed for $10 \mathrm{~s}$ and then incubated for $2.5 \mathrm{~h}$ at room temperature with continuous shaking at $400 \mathrm{rpm}$. After incubation, the tubes were decanted, washed with $2 \mathrm{~mL}$ of distilled water and decanted again. The radioactivity of each tube was measured for 1 min using a Wallac Wizard 1470 gamma counter (Perkin Elmer Life Science, Waltham, USA). The detection limit of the assay was $17 \mathrm{pg} / \mathrm{mL}$. The intra-assay coefficient of variation was $10.2 \%$. The inter-assay variation was not determined because all samples were measured in the same assay.

\section{Histological analysis of gonads}

Gonads (ovaries and testes) preserved in $4 \%$ buffered formalin were dehydrated in ethanol and embedded in paraffin using standard histological techniques. Sections of $6 \mu \mathrm{m}$ were cut using a semi-motorized rotary microtome (Leica RM2245, Leica Microsystems, Germany) and stained with haematoxylin and eosin. Slides from each gonad were examined with a light microscope (Leica HI1210, Leica Microsystems, Germany). The developmental stage of the 
gonads (ovaries and testes) was assigned according to Rocha and Rocha (2006) and Brown-Peterson et al. (2011).

\section{Statistical analysis}

Statistical analyses of data were carried out using STATISTICA 13, StatSoft software. The data were expressed as mean \pm standard error of the mean $( \pm$ SEM). Significance was accepted at $p<0.05$. For multiple comparisons of hormone concentrations (Mel, $\mathrm{T}_{4}$, $\mathrm{E}_{2}$ and 11-KT) and GSI and HSI values among control groups during all investigated phases, one-way analysis of variance (ANOVA) was performed. There were no statistically significant differences between control groups $(\mathrm{C} 1, \mathrm{C} 2$ and $\mathrm{C} 3)$ in the case of all of the investigated hormones and indexes during all investigated phases (Online Resource 1). Thus, the solvent control group (C3) was used for further analyses as a control group. For comparison of hormones' concentrations between control and $\mathrm{E}_{2}$-exposed groups during all investigated phases, unpaired Student's $t$ test was performed (Figs. 2, 3, 4 and 5).

\section{Results}

\section{Determination of $17 \beta$-estradiol concentrations in water}

The concentrations of $\mathrm{E}_{2}$ in the water of control groups' aquaria (groups $\mathrm{C} 1, \mathrm{C} 2$ and $\mathrm{C} 3$ ) were under the limits of detection, while the mean measured concentrations of $\mathrm{E}_{2}$ in aquaria of the $\mathrm{E}_{2}$-exposed group were $145.92 \pm$ $0.94 \mu \mathrm{g} / \mathrm{L}$ at the beginning and $141.39 \pm 1.43 \mu \mathrm{g} / \mathrm{L}$ at the end of each bath exposure in all of the investigated phases.

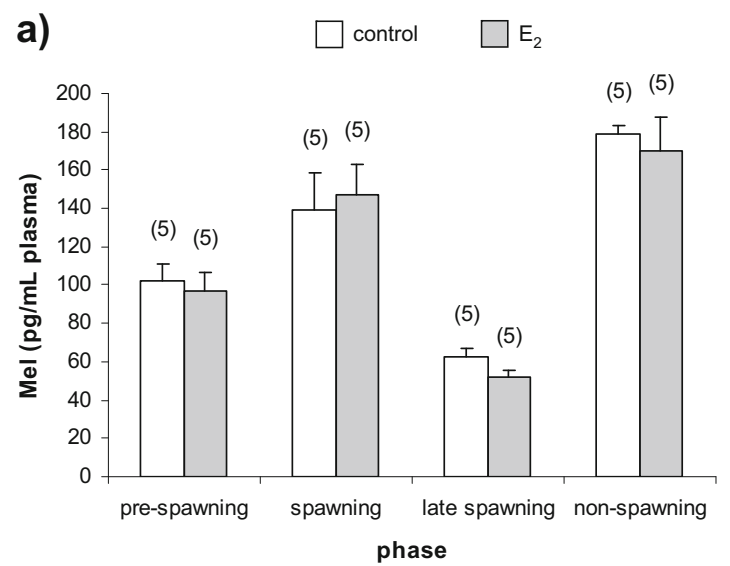

\section{Determination of environmental parameters}

During the examined phases, each group of fish was kept at a natural photoperiod, temperature and salinity (Table 1). Throughout all phases, the $\mathrm{pH}$ of water was 7.5, dissolved oxygen concentration remained $>10 \mathrm{mg} / \mathrm{L}$, nitrate $<$ $12.5 \mathrm{mg} / \mathrm{L}$, nitrite $<0.025 \mathrm{mg} / \mathrm{L}$, phosphate $<0.02 \mathrm{mg} / \mathrm{L}$ and the concentration of ammonium and ammonia remained $<$ $0.25 \mathrm{mg} / \mathrm{L}$. During each short-term bath, the parameters of water were the same in the outdoor tank as well as in indoor aquaria.

\section{Hormone concentrations in response to $17 \beta$-estradiol exposure}

\section{Plasma melatonin}

There were no statistically significant differences in plasma Mel concentrations between control and $\mathrm{E}_{2}$-exposed groups in both sexes of $N$. melanostomus in all of the phases (Fig. 2a and b).

\section{Plasma thyroxine}

In $N$. melanostomus females and males, there were no statistically significant differences in concentrations of plasma $\mathrm{T}_{4}$ in pre-spawning phase, while in other phases, plasma $\mathrm{T}_{4}$ concentrations were significantly increased in response to $\mathrm{E}_{2}$ exposure $(p<0.05)$ (Fig. 3a and $b)$.

\section{Plasma and gonadal $17 \beta$-estradiol}

In $N$. melanostomus females, the plasma and gonadal $\mathrm{E}_{2}$ concentrations were significantly elevated $(p<0.05)$ in response to exogenous $\mathrm{E}_{2}$ exposure in all of the phases (Fig. $4 \mathrm{a}$ and $\mathrm{b}$ ). In males, plasma and gonadal $\mathrm{E}_{2}$ concentrations were significantly increased $(p<0.05)$ in response to exogenous $\mathrm{E}_{2}$

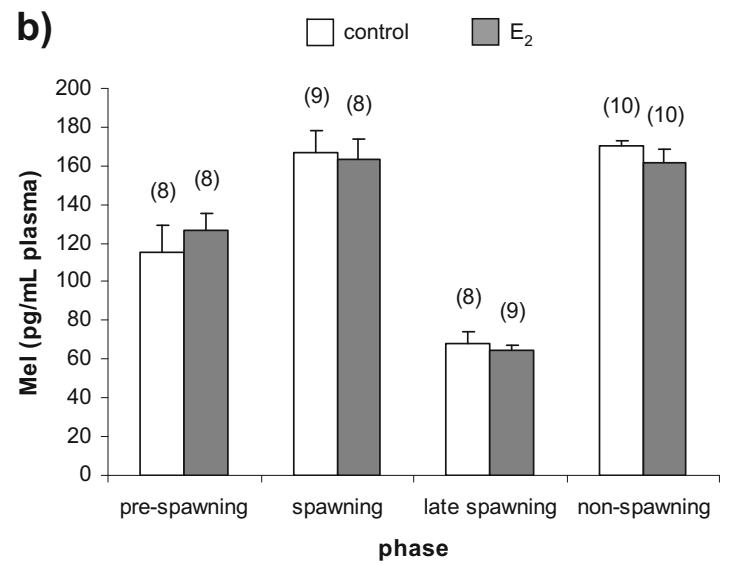

Fig. 2 Plasma Mel concentrations in (a) females and (b) males of $N$. melanostomus after exposure to waterborne $\mathrm{E}_{2}$ in different phases of the reproductive cycle. Data are presented as mean \pm SEM. The number of individuals is presented in brackets above each bar 


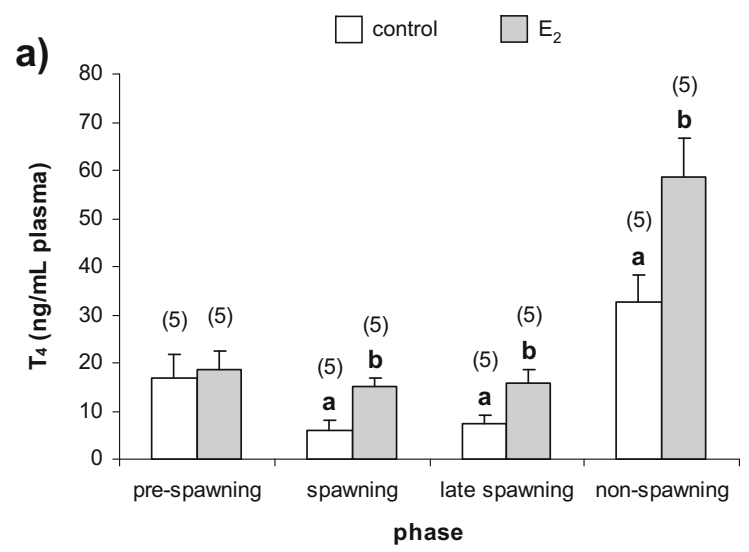

Fig. 3 Plasma $\mathrm{T}_{4}$ concentrations in (a) females and (b) males of $N$. melanostomus after exposure to waterborne $\mathrm{E}_{2}$ in different phases of the reproductive cycle. Data are presented as mean $\pm \mathrm{SEM}$. The number

exposure in pre-spawning, spawning and late spawning phases. In the non-spawning phase, a statistically significant increase $(p<0.05)$ in plasma $\mathrm{E}_{2}$ and decrease $(p<0.05)$ in gonadal $\mathrm{E}_{2}$ concentrations were noticed in males (Fig. $4 \mathrm{c}$ and d).

a)

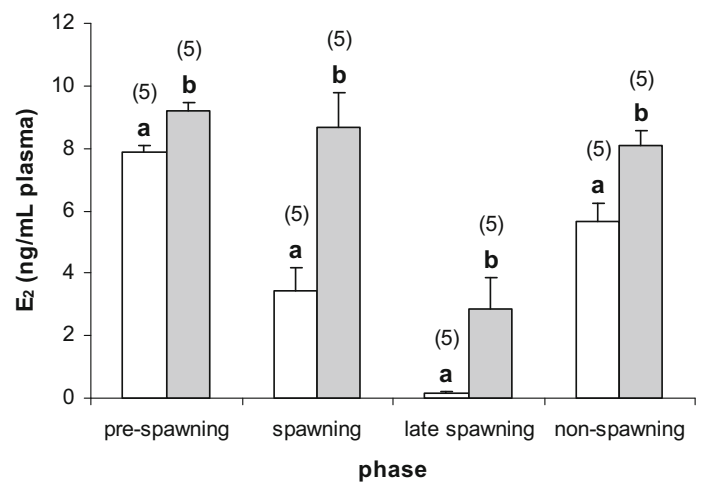

c)

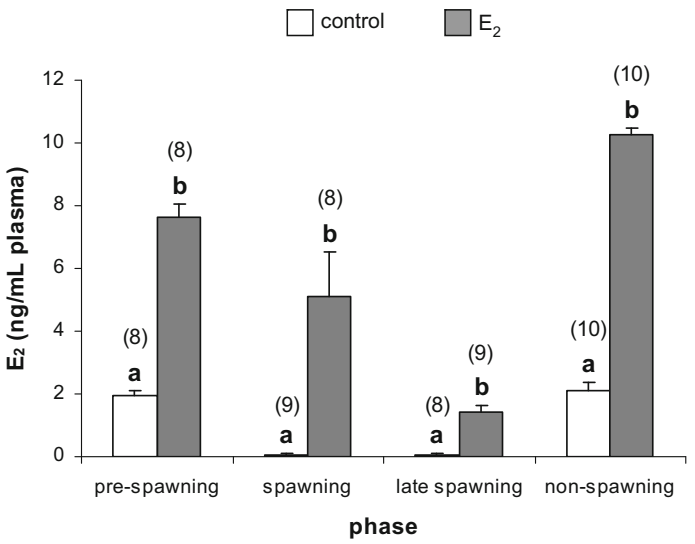

Fig. 4 Concentrations of $\mathrm{E}_{2}$ in N. melanostomus females (a) plasma, (b) gonads and males (c) plasma, (d) gonads after exposure to waterborne $\mathrm{E}_{2}$ in different phases of the reproductive cycle. Data are presented as mean \pm SEM. The number of individuals is presented in brackets above each

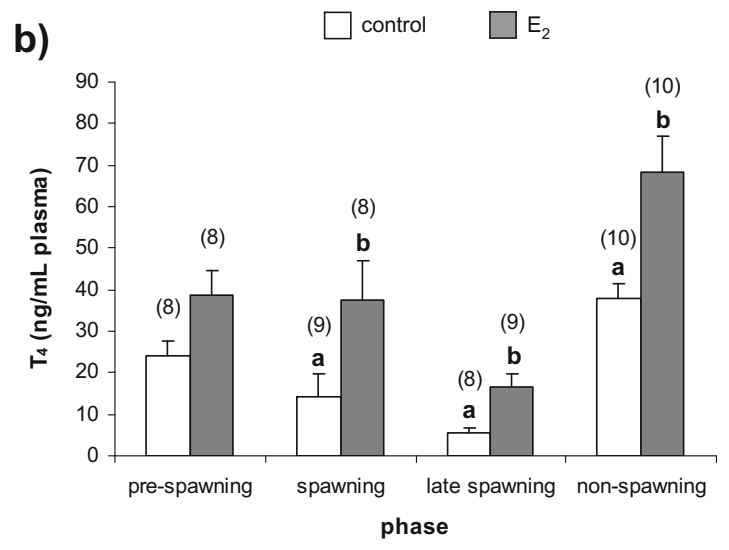

of individuals is presented in brackets above each bar. Significant differences between the control group and the group exposed to $E_{2}$ for each of the reproductive phases are given as letters $(p<0.05)$

\section{Plasma and gonadal 11-ketotestosterone}

In N. melanostomus females, both plasma and gonadal 11-KT concentrations significantly decreased $(p<0.05)$ in response to $E_{2}$ exposure in the spawning, late spawning and non-

b)

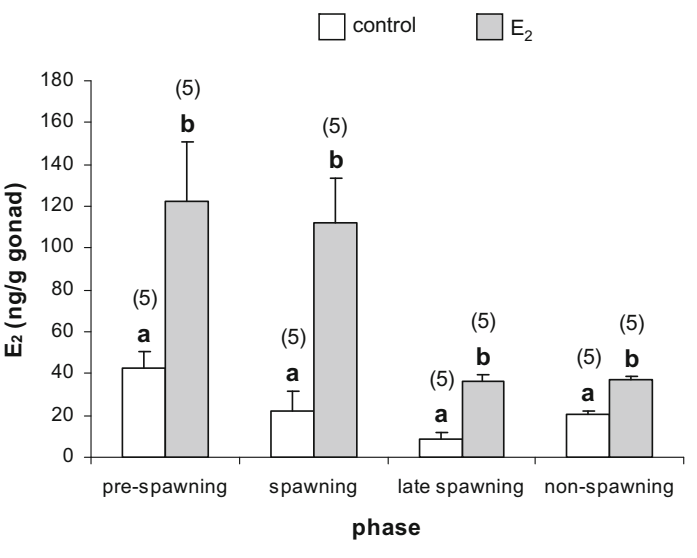

d)

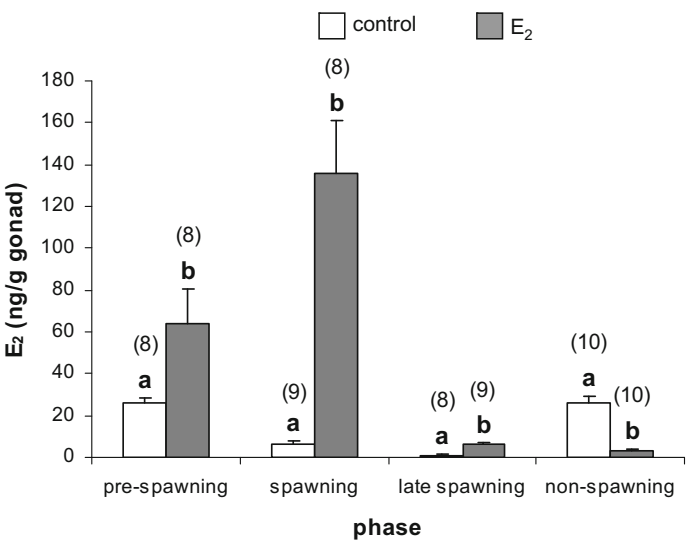

bar. Significant differences between the control group and the group exposed to $E_{2}$ for each of the reproductive phases are given as letters $(p<0.05)$ 
a)

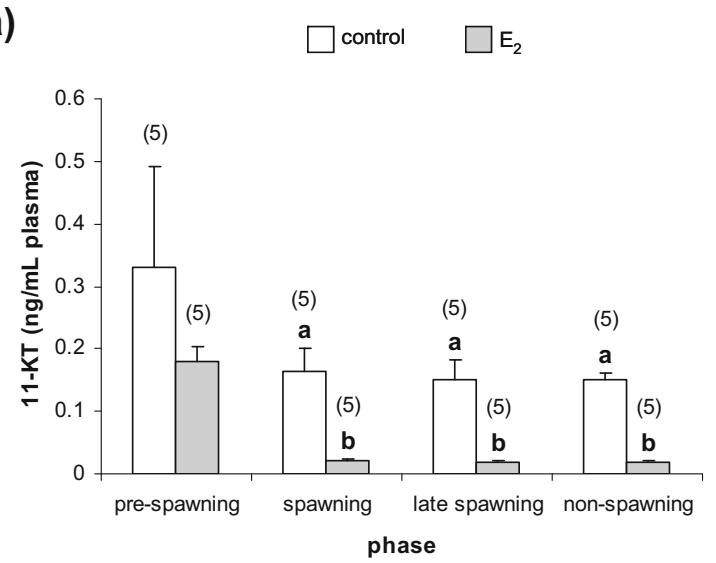

c)

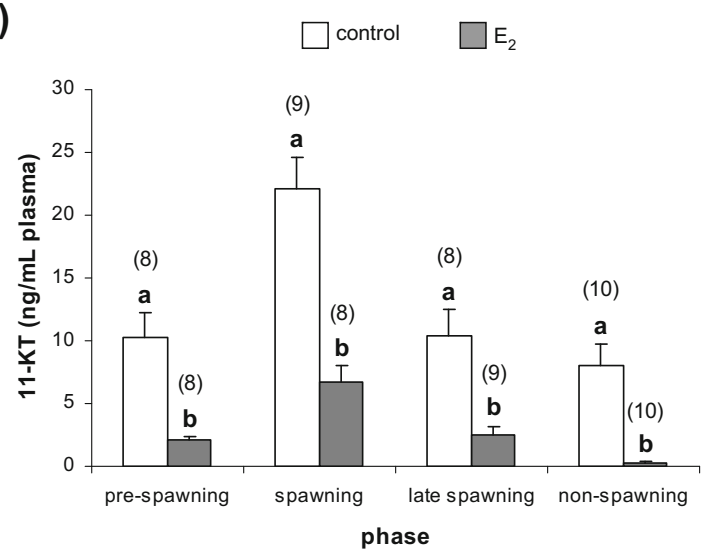

Fig. 5 Concentrations of 11-KT in N. melanostomus females (a) plasma, (b) gonads and males (c) plasma, (d) gonads after exposure to waterborne $\mathrm{E}_{2}$ in different phases of the reproductive cycle. Data are presented as mean \pm SEM. The number of individuals is presented in brackets above

spawning phases (Fig. 5a and b). Similar results were obtained in plasma 11-KT concentrations in pre-spawning phase, but differences were not statistically significant. In males, plasma and gonadal 11-KT concentrations significantly decreased $(p<0.05)$ in response to exogenous $\mathrm{E}_{2}$ exposure in all of the investigated phases (Fig. 5c and d).

\section{GSI and HSI values}

Statistically significant differences in GSI between control group and $\mathrm{E}_{2}$-exposed group $(p<0.05)$ were noticed only in the non-spawning phase for females as well as for males (Table 2). In all the examined phases, there were no statistically significant differences in HSI between the control group and $E_{2}$-exposed group in both females and males (Table 3).

\section{Histological analysis}

Histological alterations in ovaries and testes in response to $\mathrm{E}_{2}$ exposure vs. control groups were distinguished in the following phases of the reproductive cycle of $N$. melanostomus: prespawning, spawning, late spawning and non-spawning. b)

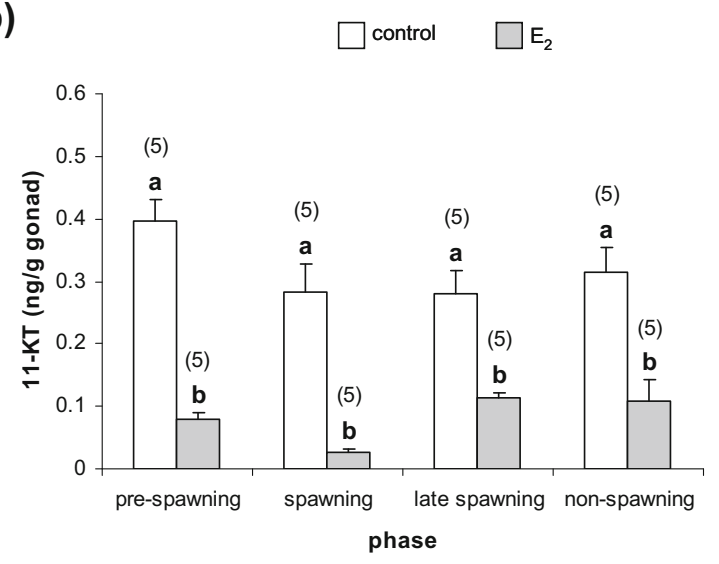

d)

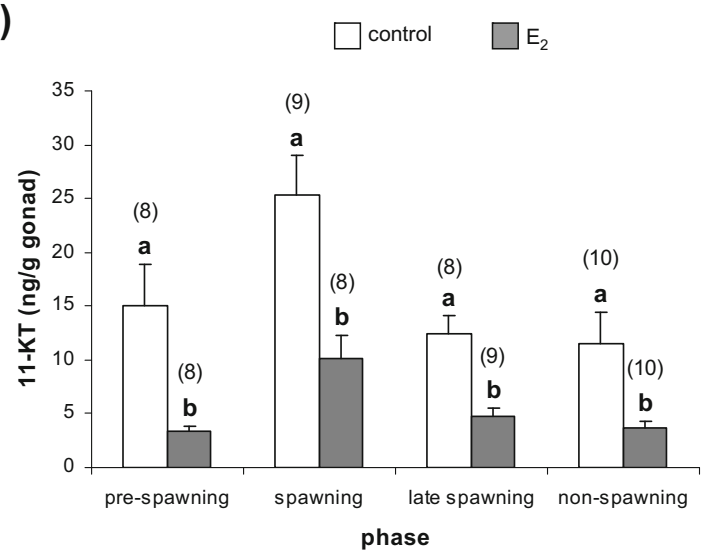

each bar. Significant differences between the control group and the group exposed to $E_{2}$ for each of the reproductive phases are given as letters $(p<0.05)$

\section{Females}

In the pre-spawning phase, no histological changes were observed in females' gonads of $N$. melanostomus exposed to $\mathrm{E}_{2}$ (Fig. 6a and b). Similar to the control groups, ovaries exposed to $\mathrm{E}_{2}$ contained mostly follicles at the late stage of vitellogenesis (VTG) and oocytes at the previtellogenic stage (PG) and early vitellogenic stage (eVTG) (Fig. 6b). In the spawning phase, the ovaries of $E_{2}$-exposed fish contained more recent postovulatory follicles (POFs) and eVTG, and sparse number of PG oocytes in comparison to the control groups (Fig. $6 \mathrm{c}$ and d). The ovaries of fish from the control groups were characterized by a large number of oocytes at the early stage of germinal vesicle migration $(\mathrm{GVM})$ and the presence of atretic postovulatory follicles (aPOFs) and the developing batches of eVTG and PG oocytes (Fig. 6c). In the late spawning phase, ovaries of females exposed to $\mathrm{E}_{2}$ in comparison to the control groups contained more $\mathrm{PG}$ and aPOFs but no recent postovulatory follicles (rPOFs) (Fig. 6e and f). The ovaries of $N$. melanostomus from the control groups contained large numbers of recent and aPOFs and oocytes during GVM, eVTG and PG (Fig. 6). In the non-spawning phase, exposure 
Table 2 Mean GSI values ( \pm SEM) for females and males of N. melanostomus in control group (C3) and $\mathrm{E}_{2}$-exposed group in different phases; significance was accepted at $p<0.05$

\begin{tabular}{llllll}
\hline GSI & & & & \\
\hline Phase & \multicolumn{1}{l}{ Females } & & & Males & \\
\cline { 2 - 3 } \cline { 5 - 6 } & Control group & $E_{2}$-exposed group & & Control group & E $_{2}$-exposed group \\
\hline Pre-spawning & $5.21 \pm 0.39$ & $6.02 \pm 0.50$ & & $1.00 \pm 0.10$ & $1.01 \pm 0.20$ \\
Spawning & $4.37 \pm 2.27$ & $4.74 \pm 0.79$ & & $1.67 \pm 0.12$ & $1.59 \pm 0.19$ \\
Late spawning & $2.08 \pm 0.68$ & $2.90 \pm 0.87$ & & $0.65 \pm 0.17$ & $0.95 \pm 0.16$ \\
Non-spawning & $2.27 \pm 0.12$ & $1.37 \pm 0.14^{*}$ & & $0.50 \pm 0.03$ & $0.30 \pm 0.02^{*}$ \\
\hline
\end{tabular}

* Statistically significant difference between the control group and $\mathrm{E}_{2}$-exposed group at $p<0.05$ to $\mathrm{E}_{2}$ resulted in the presence of larger numbers of $\mathrm{PG}$ in the ovaries of round gobies than in the control groups (Fig. $6 \mathrm{~g}$ and h). The ovaries of fish from the control groups were regressing and contained mostly vitellogenic oocytes in the early atresia stage (A) and also eVTG and PG (Fig. 6g).

\section{Males}

In the pre-spawning phase, exposure to $\mathrm{E}_{2}$ did not cause any changes in the structure of testes. Similar to the control groups, testes of fish exposed to $\mathrm{E}_{2}$ were maturing and contained spermatogonia (SG) - an undifferentiated germ cell (Fig. $7 \mathrm{a}$ and $\mathrm{b}$ ). In the spawning phase, exposure to $\mathrm{E}_{2}$ in comparison to the control groups caused a smaller number of spermatogonial cells (SG) and spermatocytes (SC) in the seminiferous tubules (ST) and less concentration of spermatozoa (SZ) in lumen of ST (Fig. 7c and d). While testes of males from the control groups were undergoing active spermatogenesis and contained a large number of SZ and clearly visible SG and SC (Fig. 7c). In the late spawning phase, exposure of $N$. melanostomus males to $\mathrm{E}_{2}$ resulted in less concentrated SZ in ST lumen in comparison to the control groups, where testes were fully matured and filled with SZ (Fig. 7e and f). In the non-spawning phase, testes of $N$. melanostomus exposed to $E_{2}$, similar to fish from the control groups, were under regression with the dominance of SGs. However, the testes of $\mathrm{E}_{2}$-exposed fish had more narrowed $\mathrm{ST}$ and smaller number of residual SZ than testes of fish from the control groups (Fig. $7 \mathrm{~g}$ and h).

Table 3 Mean HSI values $( \pm$ SEM) for females and males of $N$. melanostomus in control group (C3) and $\mathrm{E}_{2}$-exposed group in different phases; significance was accepted at $p<0.05$

\section{Discussion}

This study determined how the short-term, intermittent exposure to waterborne $\mathrm{E}_{2}$ affects $\mathrm{Mel}$ and $\mathrm{T}_{4}$ concentrations in plasma and $\mathrm{E}_{2}$ and 11-KT concentrations in plasma and gonads in mature females and males of $N$. melanostomus during four phases of the reproductive cycle defined as the pre-spawning, spawning, late spawning and non-spawning phases. The fluctuations in Mel with greatest concentrations in the spawning and non-spawning phases are not changed in response to $E_{2}$ exposure in both sexes of $N$. melanostomus. The functions of Mel in determining a time frame for spawning in both sexes of $N$. melanostomus, mainly depending on changes in temperature and photoperiod, seem to be stable in response to the supraphysiological dose of $E_{2}$ and pattern of exposure to this oestrogen. The effect of $E_{2}$ on Mel is not widely investigated in fish (Bégay et al. 1994). In rainbow trout (Oncorhynchus mykiss), it has been investigated that $\mathrm{E}_{2}$ receptors (ERs) are expressed in pineal and retina and $\mathrm{E}_{2}$ can modulate Mel secretion from pineal cell culture (Bégay et al. 1994). On the other hand, it is possible that applied dose of $\mathrm{E}_{2}$ blocks changes in Mel concentration by the dopaminergic system (Popek et al. 2010; Falcón et al. 2010; Dufour et al. 2010). It is conceivable that $E_{2}$ may act indirectly via a noradrenergic system on Mel. However, the noradrenaline control of melatonin secretion exists in some fish species and might depend on whether the photoperiodic control of Mel production by the pineal gland relies on the pineal, or the eyes, or both (Falcón et al. 2010; Migaud et al. 2007).

\begin{tabular}{|c|c|c|c|c|}
\hline \multicolumn{5}{|l|}{ HSI } \\
\hline \multirow[t]{2}{*}{ Phase } & \multicolumn{2}{|l|}{ Females } & \multicolumn{2}{|l|}{ Males } \\
\hline & Control group & $\mathrm{E}_{2}$-exposed group & Control group & $\mathrm{E}_{2}$-exposed group \\
\hline Pre-spawning & $4.60 \pm 0.39$ & $5.36 \pm 0.70$ & $4.49 \pm 0.40$ & $4.05 \pm 0.38$ \\
\hline Spawning & $4.91 \pm 0.47$ & $4.89 \pm 0.50$ & $3.98 \pm 0.28$ & $4.40 \pm 0.26$ \\
\hline Late spawning & $6.16 \pm 0.51$ & $6.38 \pm 0.50$ & $5.10 \pm 0.52$ & $4.23 \pm 0.51$ \\
\hline Non-spawning & $7.50 \pm 0.28$ & $7.23 \pm 0.45$ & $6.62 \pm 0.32$ & $5.96 \pm 0.36$ \\
\hline
\end{tabular}




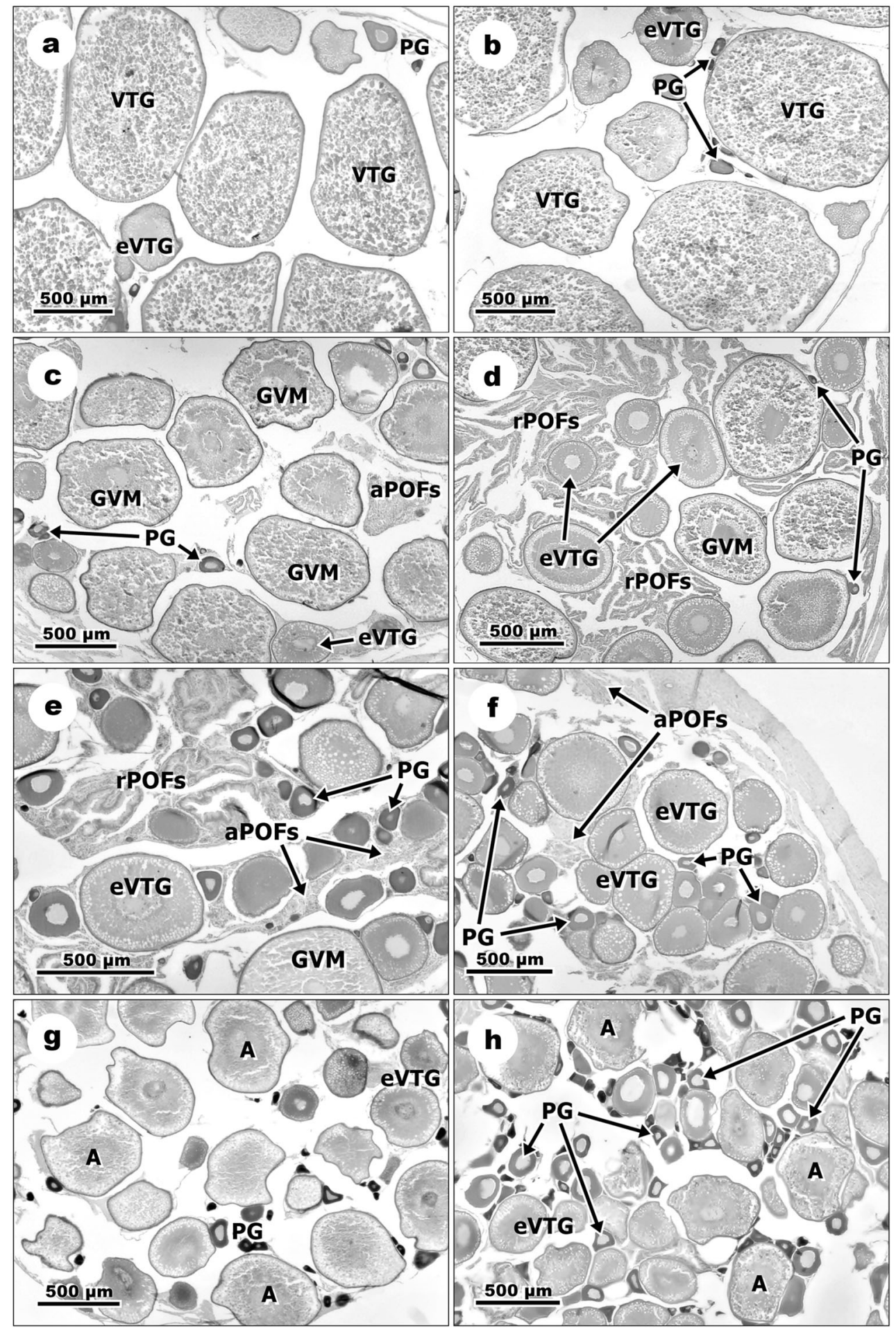

Fig. 6 Comparison of structures of $N$. melanostomus ovaries in different phases of the reproductive cycle between control and $\mathrm{E}_{2}$-exposed groups. Pre-spawning phase: (a) Ovary of a female from the control group with the dominance of developing oocytes in the late stage of vitellogenesis (VTG) and presence of previtellogenic (PG) and early vitellogenic (eVTG) oocytes; (b) Ovary of a female exposed to $\mathrm{E}_{2}$, showing the dominance of VTG oocytes and presence of PG and eVTG oocytes. Spawning phase: (c) Ovary from the control group with a large number of oocytes at the early stage of germinal vesicle migration (GVM) and presence of atretic postovulatory follicles (aPOFs) and the developing batches of eVTG and

PG oocytes; (d) Ovary of a female exposed to $E_{2}$ with recent postovulatory follicles (rPOFs) and eVTG oocytes and sparse number of PG. Late spawning phase: (e) Ovary of a female from the control group with large numbers of rPOFs and aPOFs and oocytes during GVM, eVTG and PG; (f) Ovary of a female exposed to $\mathrm{E}_{2}$ showing large numbers of $\mathrm{PG}$ and eVTG oocytes and the presence of aPOFs. Non-spawning phase: (g) Regressing ovary from control group containing mostly vitellogenic oocytes in the early atresia stage (A) and eVTG and PG oocytes; (h) Ovary of female exposed to $E_{2}$ showing large numbers of $P G$ oocytes and the presence of eVTG and A oocytes. Scale bars correspond to $500 \mu \mathrm{m}$ 
Fig. 7 Structures of

N. melanostomus testes in

different phases of the

reproductive cycle. Pre-spawning phase: (a) maturing testis with the dominance of spermatogonia (SG) of a male from the control group; (b) testis of male exposed to $E_{2}$, with the dominance of SG. Spawning phase: (c) Testis of a male from the control group under active spermatogenesis with a large number of spermatozoa (SZ) and clearly visible SG and spermatocytes (SC); (d) Testis of male exposed to $\mathrm{E}_{2}$ showing low number of $\mathrm{SG}$ and $\mathrm{SC}$ in the walls of seminiferous tubules (ST) and low concentration of SZ in the lumen of ST. Late spawning phase: (e) fully developed testis of a male from the control group with ST filled with SZ; (f) testis of a male exposed to $E_{2}$ with low concentration SZ in ST lumen. Outside spawning phase: (g) regressing testis with the dominance of SG and residual SZ in the lumen of ST; (h) testis of a male exposed to $\mathrm{E}_{2}$ with narrowed ST and low number of residual SZ. Scale bars correspond to $500 \mu \mathrm{m}$
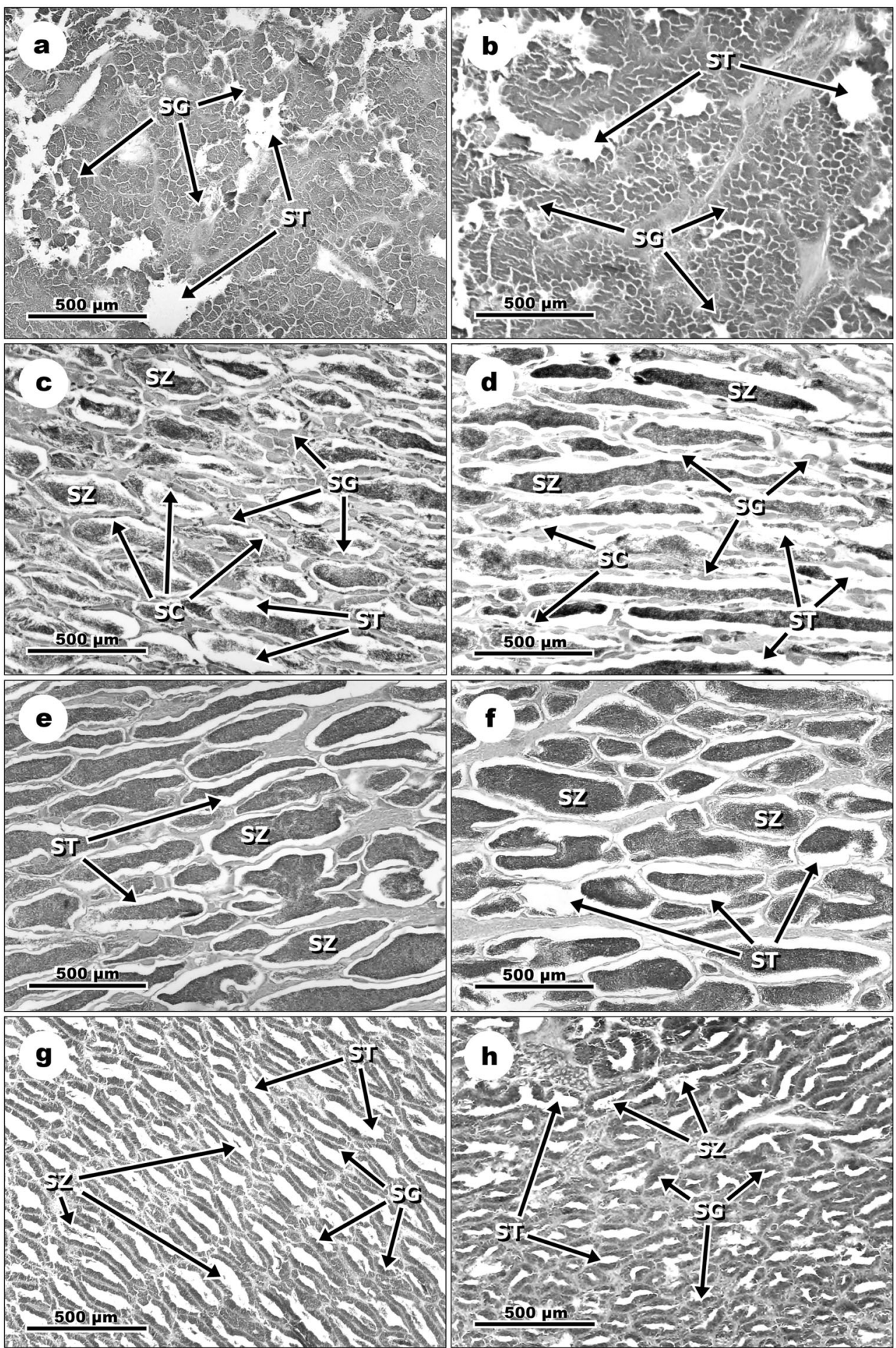

It was investigated that $\mathrm{E}_{2}$ and $\mathrm{T}_{4}$ are integral in affecting the gonadal tissues in both females and males of $N$. melanostomus during the timing of initiation of spawning and also the active spawning phase (Guellard et al. 2019). The present study indicates that exposure to $E_{2}$ enhances $T_{4}$ plasma concentrations in both sexes of $N$. melanostomus.
However, in both sexes, increase in $\mathrm{T}_{4}$ concentration was observed in all investigated phases except pre-spawning phase. Previously, the stimulating role of $E_{2}$ in thyroid activity of teleosts was observed in many fish species (Singh and Raizada 1979; Chakraborti et al. 1983; Bandyopadhyay et al. 1991). Estrogens could affect the thyroid gland, directly 
by the stimulatory effect on thyroid peroxidase activity, thyroid epithelial height, thyroidal RNA content and $\mathrm{T}_{4}$ level or indirectly through stimulation of thyroid-stimulating hormone production in the pituitary (Chakraborti and Bhattacharya 1984; Chakraborti et al. 1983; Leatherland 1985; Bandyopadhyay et al. 1991). It is possible that in the present study, the acceleration of female gonadal development in response to exogenous $E_{2}$ in the spawning, late spawning and non-spawning phases is not only due to oestrogen's action but also modulatory effect of $\mathrm{T}_{4}$ on fish gonads (Leatherland 1988; Raine 2011; Habibi et al. 2012). Nevertheless, the effect of $E_{2}$ on thyroid function in fish seems to be by no means universal because there are studies in which $\mathrm{E}_{2}$ has been shown to have an inhibitory or no effect on the thyroid (Leatherland 1985; Cyr et al. 1988). In females of $N$. melanostomus, there was no effect of exogenous $\mathrm{E}_{2}$ on plasma $\mathrm{T}_{4}$ concentrations as well as on ovarian histology in the pre-spawning phase. The influence of $E_{2}$ on thyroid activity has not been widely studied in teleost males, although the stimulatory effect of $\mathrm{E}_{2}$ was recognized in $O$. mykiss (Leatherland 1985). The interaction of oestrogen and thyroid hormones may also be explained by cross-talk or crossregulation between reproductive and thyroidal systems through gene expression changes in nuclear ERs and deiodinase enzymes as was documented in the male goldfish (Carassius auratus) (Marlatt et al. 2012; Nelson and Habibi 2016).

The results presented here demonstrate that exogenous $E_{2}$ affects sex steroid concentrations in plasma and gonads in both females and males of $N$. melanostomus during all examined phases of the reproductive cycle. In females of $N$. melanostomus, exposure to $\mathrm{E}_{2}$ significantly increases plasma and ovarian $E_{2}$ concentrations independently of the investigated phases. The stimulatory effect of exogenous $E_{2}$ on plasma $\mathrm{E}_{2}$ concentration was examined inter alia in mature females of $O$. mykiss, Chinese rare minnow (Gobiocypris rarus), three-spined stickleback (Gasterosteus aculeatus) and C. auratus (Flett and Leatherland 1989; MilesRichardson et al. 1999; Maunder et al. 2007; Tarkhani et al. 2012). It should be mentioned that in fish, estrogenic effects may also be mediated by elevation of endogenous free plasma oestrogen levels caused by competitive binding of estrogens to sex steroid binding globulins (Tollefsen 2002). However, estrogens may influence the HPG axis primarily by modulating steroid synthesis or by regulatory feedback mechanisms. The stimulatory effect of $E_{2}$ on gonadal $E_{2}$ synthesis and plas$\mathrm{ma}_{2}$ level in fish females is implied by the increased gonadal expression of cyp $19 b$ the gene encoding the enzyme responsible for the conversion (aromatization) of androgens to estrogens (Halm et al. 2002; Filby et al. 2006). Exogenous $E_{2}$ also increased gonadal expression of genes cyp 17 and hsd $17 \mathrm{~b}$ encoding enzymes which, through their role in androgen production, also affect the production of estrogens (Filby et al.
2006). The $\mathrm{E}_{2}$ effect on 11-KT was quite opposite, reduction of this steroid concentrations in plasma and ovaries in all examined phases of the reproductive cycle. To the authors' knowledge, there is no available information about the effect of $E_{2}$ on 11-KT concentration in mature fish females. Nonetheless, in mature females of fathead minnow (Pimephales promelas), down-regulation of gonadal expression of $h s d 11 b$ gene encoding enzyme essential in 11-KT synthesis was observed in response to $17 \alpha$-ethinylestradiol and $E_{2}$ (Filby et al. 2006, 2007). It is possible that downregulation of expression of $h s d 11 b$ gene may be directly responsible for the decrease in gonadal 11-KT concentration also in $N$. melanostomus females.

In $N$. melanostomus male, exposure to exogenous $\mathrm{E}_{2}$ significantly increased plasma $\mathrm{E}_{2}$ concentration during all investigated phases. The stimulatory $\mathrm{E}_{2}$ effect on gonadal concentrations of $E_{2}$ was revealed in pre-spawning, spawning and late spawning phases. In the nonspawning phase, exposure to exogenous $\mathrm{E}_{2}$ reduced native $\mathrm{E}_{2}$ concentration in testes. Furthermore, the decrease in plasma and gonadal 11-KT concentrations, in response to exogenous $E_{2}$ was observed independently of investigated phases. The stimulatory effect of $E_{2}$ on plasma $E_{2}$ concentrations was well established in many fish males, e.g., O. mykiss, P. promelas and C. auratus (Flett and Leatherland 1989; Miles-Richardson et al. 1999; Bjerselius et al. 2001). Furthermore, the exposure to exogenous $E_{2}$ was shown to induce plasma and gonadal $E_{2}$ increase as well as testosterone and 11-KT decrease and testicular regression and feminization (Chang et al. 1995; Condeça and Canario 1999; Yamaguchi et al. 2006). There were two potential mechanisms involved in oestrogen's exogenous effect in fish males, first, when $E_{2}$ induces classic biomarkers of oestrogen responses such as hepatic ER1 expression and plasma Vtg, and second when $E_{2}$ impacts on the HPG axis through changing steroidogenic enzyme expression profiles (Filby et al. 2006; $\mathrm{Kim}$ et al. 2010). Although it was presumed that liver Vtg mRNA expression or Vtg accumulation in testes may correlate with changes in gonad morphology and function, and the prevalence of intersex and feminization in teleost males, the effect of estradiol on androgen synthesis via the feminization of the expression profiles for steroidogenic enzymes appears more plausible in most fish species (Trudeau et al. 1991; Govoroun et al. 2001; Halm et al. 2002; Baron et al. 2005; Filby et al. 2006). For genes encoding key enzymes in the production of androgens in males, expression of cyp 17, hsd11b2, hsd $17 \mathrm{~b}$ and star were down-regulated, suppressing the testicular steroidogenic capacity by decreasing $11-\mathrm{KT}$ release in $\mathrm{E}_{2}$ exposed fish males (Govoroun et al. 2001; Filby et al. 2006; de Waal et al. 2009). In contrast, expression of cyp $19 b$ was up-regulated in $\mathrm{E}_{2}$-treated males (Halm 
et al. 2002; Filby et al. 2006). This suppression of "male" steroidogenic enzymes by estrogens may be caused via a negative feedback of $E_{2}$ on the follicle-stimulating hormone; however, studies on O. mykiss, Atlantic croaker (Micropogonias undulatus) and red sea bream (Pagrus major) suggest a direct action of $\mathrm{E}_{2}$ on the testes, independently of gonadotropin stimulation (Govoroun et al. 2001; Baron et al. 2005; Yamaguchi et al. 2006). It is possible that the presented mechanisms involved in oestrogen's effects may occur in $N$. melanostomus males in all investigated phases of the reproduction cycle except non-spawning. In the non-spawning phase, exogenous $\mathrm{E}_{2}$ exposure increased plasma $\mathrm{E}_{2}$ concentration and reduced $\mathrm{E}_{2}$ and 11-KT concentrations in testes. It is possible that a very high plasma $\mathrm{E}_{2}$ concentration, as a result of exposure to $\mathrm{E}_{2}$, may act via the negative feedback, directly on synthesis and release of GnRH within the hypothalamus and gonadotropin from the pituitary or indirectly through upregulation of dopamine synthesis and dopamine receptor mRNA in the brain (reviewed in Dufour et al. 2010; Yaron and Levavi-Sivan 2011). However, in male C. auratus in the mid-recrudescence phase it was found that $\mathrm{E}_{2}$ did not affect luteinizing hormone secretion but acts directly on the testes probably via a short loop feedback blocking the cytochrome P450 17A1 (17 $\alpha$-hydroxylase-C17, 20-lyase), enzyme responsible for the formation of androstenedione in the pathway of steroidogenesis (Trudeau et al. 1991, 1993). In conclusion, it may be assumed that $\mathrm{E}_{2}$ has a direct action on testes and indirect action on gonadotrophins in $N$. melanostomus males.

The short exposure to a supraphysiological dose of $E_{2}$ causes not only changes in thyroxine and sex steroids levels but also influence gonad's histology in both sexes of $N$. melanostomus. In the pre-spawning phase in females of $N$. melanostomus, exposure to $\mathrm{E}_{2}$ seems to have no effect on ovarian development. Probably, $N$. melanostomus ovaries are not sensitive to an additional dose of $\mathrm{E}_{2}$ when their own $\mathrm{E}_{2}$ concentration in plasma and gonads are very high or this exposure is too short to provoke histological changes. In the spawning phase, exogenous $E_{2}$ has accelerated ovulation and development of eVTG oocytes. Similar results have been reported in C. auratus and A. anguilla (Olivereau and Olivereau 1979; Pankhurst and Stacey 1985). In the late spawning phase, in ovaries of $N$. melanostomus, exposure to $\mathrm{E}_{2}$ induced PG and eVTG oocytes growth, increasing their number and stimulated atresia of POFs. In regressing ovaries of $N$. melanostomus in the non-spawning phase, exogenous $\mathrm{E}_{2}$ also induced PG oocytes' growth. Furthermore, it was observed that in $N$. melanostomus as in other fish females, high concentration of $\mathrm{E}_{2}$ in plasma and gonads may also be caused by persisting steroidogenesis of atretic vitellogenic oocytes (Rinchard et al. 1993; Guellard et al. 2019). It is possible that exogenous estradiol strengthens not only the steroidogenesis in atretic oocytes but also in previtellogenic oocytes, accelerating their development in $N$. melanostomus.

In the pre-spawning phase in males of $N$. melanostomus, exposure to $\mathrm{E}_{2}$ did not affect the structure of maturing testes. In this phase, similarly to females, exogenous $E_{2}$ seems to have no effect on gonadal development. Testes might not be sensitive to the applied dose of $\mathrm{E}_{2}$ because endogenous plasma and gonadal $E_{2}$ concentrations are already high or the exposure time is not sufficient to interfere with gonadal structure. In the spawning phase, the results indicate a significant inhibitory effect of $\mathrm{E}_{2}$ on $N$. melanostomus spermatogenesis. Similar observations after exposure to $\mathrm{E}_{2}$ have been noticed in zebrafish (Danio rerio) and O. mykiss (Lahnsteiner et al. 2006; de Waal et al. 2009). In the late spawning phase, $N$. melanostomus males' exposure to $\mathrm{E}_{2}$ caused partial inhibition of spermiogenesis as was observed in O. mykiss (Lahnsteiner et al. 2006). Furthermore, in N. melanostomus males as well as in males of other fish species such as Japanese huchen (Hucho perryi), spotted murrel (Channa punctatus) or gilthead seabream (Sparus aurata), the high concentration of $\mathrm{E}_{2}$ in testes in non-spawning phase have been associated with the suppression of spermatogenesis, inhibition of spermatogonial proliferation and induction of spermatogonial atresia (Amer et al. 2001; Chaves-Pozo et al. 2007; Basak et al. 2016; Guellard et al. 2019). It is possible that exogenous $E_{2}$ together with the high level of native $\mathrm{E}_{2}$ might accelerate the regression of testes in N. melanostomus.

Significant differences in GSI between control group and $\mathrm{E}_{2}$-exposed group was noticed only in the non-spawning phase for both sexes. Similar results were noticed in both sexes in many fish species during development and spawning capable phases (Medda et al. 1980; Kang et al. 2002; de Waal et al. 2009). Furthermore, it should be mentioned here that the GSI is apparently a less reliable assessment of the stage of sexual maturation in batch spawners, such as N. melanostomus (Zeyl et al. 2014). The decrease in GSI caused by the administration of $\mathrm{E}_{2}$ in the non-spawning phase can be explained by progressive ovarian regression and a changing proportion between the number of atretic and developing oocytes in females and by progressive testicular regression in males of $N$. melanostomus. Moreover, in all examined phases, there were no significant differences in HSI between control group and $\mathrm{E}_{2}$-exposed group in both sexes. Probably this exposure to $E_{2}$ is too short to provoke considerable liver hypertrophy or other morphological changes. No changes in HSI after exposure to $E_{2}$ have also been reported in both sexes of Japanese medaka (Oryzias latipes) by Kang et al. (2002).

\section{Conclusion}

This is the first study to determine the influence of short-term, intermittent exposure to a supraphysiological concentration of 
waterborne $\mathrm{E}_{2}$ on Mel and $\mathrm{T} 4$ concentrations in plasma and $\mathrm{E}_{2}$ and 11-KT concentrations in plasma and gonads, supported by histological analysis of gonads, in both sexes of $N$. melanostomus during the reproductive cycle.

In the present study, Mel level is unchanged in the short time exposure to a supraphysiological dose of $\mathrm{E}_{2}$ during investigated phases and its role in determining a time frame for spawning in $N$. melanostomus females and males seems to be stable in those conditions. It should be noted that this stable level of Mel can protect against serious histopathological changes in gonads as a consequence of $\mathrm{E}_{2}$ exposure. However, $\mathrm{T}_{4}$ and sex steroids $\left(\mathrm{E}_{2}\right.$ and $11-\mathrm{KT}$ ) were sensitive to even short exposure to $E_{2}$. It is possible that $\mathrm{T}_{4}$ and sex steroids are integral in affecting the gonads of $N$. melanostomus by hastening oocyte development, ovulation and regression and inhibiting spermatogenesis in response to exogenous $\mathrm{E}_{2}$ during the reproductive cycle. It seems that hormonal changes due to estradiol exposure cause greater disturbances in the reproduction of males than females. In males, there is shortening spawning and fertility disturbances. In turn, in females, the acceleration in oocyte development, ovulation and regression may paradoxically enhance their reproductive potential.

In conclusion, the results presented here indicate that $N$. melanostomus representing all investigated phases are sensitive to endocrine disruption caused by $\mathrm{E}_{2}$ and that those physiological responses were altered over a short window of exposure, indicating the potential for a supraphysiological dose of this compound to impact teleosts in coastal zones, exposed to discharges from large urban agglomerations and runoff from animal agricultural wastes. Hence, the applied procedure using intermittent waterborne $\mathrm{E}_{2}$ exposure mimicking environmental conditions influences the reproductive physiology of fish. N. melanostomus can also be recommended as a very suitable model for studying endocrine disruptors because they are sensitive to even a short exposure to $E_{2}$.

Acknowledgments The authors would like to thank K.E. Skóra from the Hel Marine Station of the Institute of Oceanography (University of Gdańsk) for providing technical support and access to the laboratory facilities at the Hel Marine Station. The authors would like to thank E. Kulczykowska for valuable advices during the planning and realization of this study.

Funding information This study was financially supported by the National Science Centre of Poland (grant no. DEC- 2012/05/N/NZ8/ 00739).

\section{Compliance with ethical standards}

All procedures performed in this study complied with the EC Directive 2010/63/EU for animal experiments and with the guidelines of the Local Ethics Committee on Animal Experimentation (Resolutions No. 33/2010 and 2/2012).

Conflict of interest The authors declare that they have no conflict of interest.
Open Access This article is licensed under a Creative Commons Attribution 4.0 International License, which permits use, sharing, adaptation, distribution and reproduction in any medium or format, as long as you give appropriate credit to the original author(s) and the source, provide a link to the Creative Commons licence, and indicate if changes were made. The images or other third party material in this article are included in the article's Creative Commons licence, unless indicated otherwise in a credit line to the material. If material is not included in the article's Creative Commons licence and your intended use is not permitted by statutory regulation or exceeds the permitted use, you will need to obtain permission directly from the copyright holder. To view a copy of this licence, visit http://creativecommons.org/licenses/by/4.0/.

\section{References}

Adeel M, Song X, Wang Y, Francis D, Yang Y (2017) Environmental impact of estrogens on human, animal and plant life: a critical review. Environ Int 99:107-119. https://doi.org/10.1016/j.envint. 2016.12.010

Afifi R, Elnwishy N, Hannora A, Hedström M, Mattiasson B, Omran H, Alharbi OML, Ali I (2016) SPE and HPLC monitoring of 17- $\beta$ estradiol in Egyptian aquatic ecosystems. J Liq Chromatogr Relat Technol 39:428-434. https://doi.org/10.1080/10826076.2016. 1174712

Amer MA, Miura T, Miura C, Yamauchi K (2001) Involvement of sex steroid hormones in the early stages of spermatogenesis in Japanese huchen (Hucho perryi). Biol Reprod 65:1057-1066. https://doi.org/ 10.1095/biolreprod65.4.1057

Bandyopadhyay S, Banerjee PP, Bhattacharya S (1991) 17 $\beta$-Estradiol releases thyroxine from the thyroid follicles of a teleost, Channa gachua (Ham.). Gen Comp Endocrinol 81:227-233. https://doi. org/10.1016/0016-6480(91)90007-S

Baron D, Fostier A, Breton B, Guiguen Y (2005) Androgen and estrogen treatments alter steady state messenger RNA (mRNA) levels of testicular steroidogenic enzymes in the rainbow trout, Oncorhynchus mykiss. Mol Reprod Dev 71:471-479. https://doi. org $/ 10.1002 / \mathrm{mrd} .20229$

Basak R, Roy A, Rai U (2016) Seasonality of reproduction in male spotted murrel Channa punctatus: correlation of environmental variables and plasma sex steroids with histological changes in testis. Fish Physiol Biochem 42:1249-1258. https://doi.org/10.1007/ s10695-016-0214-6

Bégay V, Valotaire Y, Ravault JP, Collin JP, Falcon J (1994) Detection of estrogen receptor mRNA in trout pineal and retina: estradiol-17 $\beta$ modulates melatonin production by cultured pineal photoreceptor cells. Gen Comp Endocrinol 93:61-69. https://doi.org/10.1006/ gcen.1994.1008

Bjerselius R, Lundstedt-Enkel K, Olsén H, Mayer I, Dimberg K (2001) Male goldfish reproductive behaviour and physiology are severely affected by exogenous exposure to $17 \beta$-estradiol. Aquat Toxicol 53: 139-152. https://doi.org/10.1016/S0166-445X(00)00160-0

Borg B (1994) Androgens in teleost fishes. Comp. Biochem. Physiol C Pharmacol Toxicol Endocrinol 109:219-245. https://doi.org/10. 1016/0742-8413(94)00063-G

Bowley LA (2010) Endocrine disruption in round goby (Neogobius melanostomus) from Hamilton Harbour. Dissertation, McMaster University

Bowley LA, Alam F, Marentette JR, Balshine S, Wilson J (2010) Characterization of vitellogenin gene expression in round goby (Neogobius melanostomus) using a quantitative polymerase chain reaction assay. Environ Toxic Chem 29:2751-2760. https://doi.org/ $10.1002 /$ etc. 324 
Brown-Peterson NJ, Wyanski DM, Saborido-Rey F, Macewicz BJ, Lowerre-Barbieri SK (2011) A standardized terminology for describing reproductive development in fishes. Mar Coastal Fish 3: 52-70. https://doi.org/10.1080/19425120.2011.555724

Chakraborti P, Rakshit DK, Bhattacharya S (1983) Influence of season, gonadotropins, and gonadal hormones on the thyroid activity of freshwater perch, Anabas testudineus (Bloch). Gen Comp Endocrinol 53:179-186. https://doi.org/10.1139/z83-047

Chakraborti P, Bhattacharya S (1984) Plasma thyroxine levels in freshwater perch: influence of season, gonadotropins, and gonadal hormones. Gen Comp Endocrinol 53:179-186. https://doi.org/10.1016/ 0016-6480(84)90240-5

Chang C-F, Lau E-L, Lin B-Y (1995) Estradiol-17ß suppresses testicular development and stimulates sex reversal in protandrous black porgy, Acanthopagrus schlegeli. Fish Physiol Biochem 14:481-488. https://doi.org/10.1007/BF00004348

Chaves-Pozo E, Liarte S, Vargas-Chacoff L, García-López A, Mulero V, Meseguer J, Mancera JM, García-Ayala A (2007) 17Beta-estradiol triggers post spawning in spermatogenically active gilthead seabream (Sparus aurata L.) males. Biol Reprod 76:142-148. https://doi.org/10.1095/biolreprod.106.056036

Condeça JB, Canario AVM (1999) The effect of estrogen on the gonads and on in vitro conversion of androstenedione to testosterone, 11ketotestosterone, and estradiol-17 $\beta$ in Sparus aurata (Teleostei, Sparidae). Gen Comp Endocrinol 116:59-72. https://doi.org/10. 1006/gcen.1999.7338

Cyr DG, MacLatchy DL, Eales JG (1988) The influence of short-term $17 \beta$-estradiol treatment on plasma $T_{3}$ levels and in vitro hepatic $T_{4}$ 5 -monodeiodinase activity in immature rainbow trout, Salmo gairdneri. Gen Comp Endocrinol 69:431-438. https://doi.org/10. 1016/0016-6480(88)90035-4

Demska-Zakeś K (2005) Effect of select xenobiotics on the development of the fish reproductive system. In: Dissertations and monographs, Wydawnictwo UWM, Olsztyn, vol 103, pp 1-61 (in Polish)

Desbrow C, Routledge EJ, Brighty GC, Sumpter JP, Waldock M (1998) Identification of estrogenic chemicals in STW effluent. 1. Chemical fractionation and in vitro biological screening. Environ. Sci Technol 32:1549-1558. https://doi.org/10.1021/es9707973

de Waal PP, Leal MC, García-López A, Liarte S, de Jonge H, Hinfray N, Brion F, Schulz RW, Bogerd J (2009) Oestrogen-induced androgen insufficiency results in a reduction of proliferation and differentiation of spermatogonia in the zebrafish testis. J Endocrinol 202:287297. https://doi.org/10.1677/JOE-09-0050

Dietrich DR, Krieger HO (2009) Endocrine-disrupting compounds. In: Dietrich DR, Krieger HO (eds) Histological analysis of endocrinedisruptive effects in small laboratory fish. Wiley, Hoboken, pp 115 246. https://doi.org/10.1002/9780470431795.ch6

Dufour S, Sebert ME, Weltzien FA, Rousseau K, Pasqualini C (2010) Neuroendocrine control by dopamine of teleost reproduction. J Fish Biol. 76:129-160. https://doi.org/10.1111/j.1095-8649.2009.02499. $\mathrm{x}$

Elnwishy N, Hanora A, Hedström M, Afifi R, Mattiasson B, Omran H (2012) Monitoring of $17 \beta$-estradiol residues in the Suez Canal Region. Egypt J Aquat Biol Fish 16:73-81. https://doi.org/10. 21608/EJABF.2012.2126

Falkenstein E, Tillmann HC, Christ M, Feuring M, Wehling M (2000) Multiple actions of steroid hormones - a focus on rapid, nongenomic effects. Pharmacol Rev 52:513-556

Falcón J, Migaud H, Muñoz-Cueto JA, Carrillo M (2010) Current knowledge on the melatonin system in teleost fish. Gen Comp Endocrinol 165:469-482. https://doi.org/10.1016/j.ygcen.2009.04.026

Filby AL, Thorpe KL, Tyler CR (2006) Multiple molecular effect pathways of an environmental oestrogen in fish. J Mol Endocrinol 37: 121-134. https://doi.org/10.1677/jme.1.01997

Filby AL, Thorpe KL, Maack G, Tyler CR (2007) Gene expression profiles revealing the mechanisms of anti-androgen- and estrogen- induced feminization in fish. Aquat Toxicol 81:219-231. https:// doi.org/10.1016/j.aquatox.2006.12.003

Flett PA, Leatherland JF (1989) Dose-related effects of $17 \beta$-oestradiol $\left(E_{2}\right)$ on liver weight, plasma $E_{2}$, protein, calcium and thyroid hormone levels, and measurement of the binding of thyroid hormones to vitellogenin in rainbow trout, Salmo gairdneri Richardson. J Fish Biol 34:515-527. https://doi.org/10.1111/j.1095-8649.1989. tb03332.x

Fuzzen MLM, Bernier NJ, Van Der Kraak G (2011) Differential effects of $17 \beta$-estradiol and 11-ketotestosterone on the endocrine stress response in zebrafish (Danio rerio). Gen Comp Endocrinol 170: 365-373. https://doi.org/10.1016/j.ygcen.2010.10.014

Goryczko K, Bieniarz K, Dobosz S, Grudniewska J (1991) The effects of $17 \beta$-estradiol on rainbow trout (Oncorhynchus mykiss Walb.) [Sex Control]. Pol Arch Hydrobiol 38:303-309

Govoroun M, McMeel OM, Mecherouki H, Smith TJ, Guiguen Y (2001) $17 \beta$-Estradiol decreases steroidogenic enzyme messenger ribonucleic acid levels in the rainbow trout testis. Endocrinology 142: 1841-1848. https://doi.org/10.1210/endo.142.5.8142

Guellard T, Sokołowska E, Arciszewski B (2015) First report on intersex in invasive round goby Neogobius melanostomus from the Baltic Sea (Gulf of Gdańsk, Poland). Oceanologia 57:102-106. https://doi. org/10.1016/j.oceano.2014.09.004

Guellard T, Kalamarz-Kubiak H, Kulczykowska E (2019) Concentrations of melatonin, thyroxine, $17 \beta$-estradiol and 11ketotestosterone in round goby (Neogobius melanostomus) in different phases of the reproductive cycle. Anim Reprod Sci 204:10 21. https://doi.org/10.1016/j.anireprosci.2019.02.014

Habibi HR, Nelson ER, Allan ER (2012) New insights into thyroid hormone function and modulation of reproduction in goldfish. Gen Comp Endocrinol 175:19-26. https://doi.org/10.1016/j.ygcen. 2011.11.003

Halm S, Pounds N, Maddix S, Rand-Weaver M, Sumpter JP, Hutchinson TH, Tyler CR (2002) Exposure to exogenous $17 \beta$-oestradiol disrupts $\mathrm{P} 450$ aromB mRNA expression in the brain and gonad of adult fathead minnows (Pimephales promelas). Aquat Toxicol 60:285299. https://doi.org/10.1016/S0166-445X(02)00011-5

Hunter GA, Donaldson EM (1983) Hormonal sex control and its application to fish culture. In: Hoar WS, Randall DJ, Donaldson EM (eds) Fish physiology, vol IX, part B, behaviour and fertility control. Academic Press, New York, pp 223-303. https://doi.org/10.1016/ S1546-5098(08)60305-2

Hyndman KM, Biales A, Bartell SE, Schoenfuss HL (2010) Assessing the effects of exposure timing on biomarker expression using $17 \beta$ estradiol. Aquat Toxicol 96:264-272. https://doi.org/10.1016/j. aquatox.2009.11.004

Kalamarz-Kubiak H, Gozdowska M, Guellard T, Kulczykowska E (2017) How does oestradiol influence the AVT/IT system in female round gobies during different reproductive phases? Biol Open 6: 1493-1501. https://doi.org/10.1242/bio.024844

Kang IJ, Yokota H, Oshima Y, Tsuruda Y, Yamaguchi T, Maeda M, Imada N, Tadokoro H, Honjo T (2002) Effect of $17 \beta$-estradiol on the reproduction of Japanese medaka (Oryzias latipes). Chemosphere 47:7180. https://doi.org/10.1016/S0045-6535(01)00205-3

Kim DS, Nam YK, Jo J-Y (1997) Effect of estradiol-17ß immersion treatments on sex reversal of mud loach, Misgurnus mizolepis (Günter). Aquac Res 28:941-946. https://doi.org/10.1046/j.13652109.1997.00925.x

Kim NN, Jin DH, Lee J, Kil GS, Choi CY (2010) Upregulation of estrogen receptor subtypes and vitellogenin mRNA in cinnamon clownfish Amphiprion melanopus during the sex change process: profiles on effects of $17 \beta$-estradiol. Comp Biochem Physiol B Biochem Mol Biol 157:198-204. https://doi.org/10.1016/j.cbpb. 2010.06.003

Kornis MS, Mercado-Silva N, Vander Zanden MJ (2012) Twenty years of invasion: a review of round goby Neogobius melanostomus 
biology, spread and ecological implications. J Fish Biol 80:235285. https://doi.org/10.1111/j.1095-8649.2011.03157.x

Kramer VJ, Miles-Richardson S, Pierens SL, Giesy JP (1998) Reproductive impairment and induction of alkaline-labile phosphate, a biomarker of estrogen exposure, in fathead minnows (Pimephales promelas) exposed to waterborne $17 \beta$-estradiol. Aquat Toxicol 40:335-360. https://doi.org/10.1016/S0166$445 \mathrm{X}(97) 00060-\mathrm{X}$

Kulczykowska E, Kasprzak M, Kalamarz H, Kuriata M, Nietrzeba M, Jerzak L, Kamiński P (2007) Melatonin and thyroxine response to pollution in white stork nestlings (Ciconia ciconia): aspects of rhythmicity and age. Comp Biochem Physiol C Toxicol Pharmacol 146: 392-397. https://doi.org/10.1016/j.cbpc.2007.04.012

Kulczykowska E, Kalamarz-Kubiak H, Nietrzeba M, Gozdowska M (2015) Brain nonapeptide and gonadal steroid responses to deprivation of heterosexual contact in the black molly. Biol Open 4:69-78. https://doi.org/10.1242/bio.20149597

Lahnsteiner F, Berger B, Kletzl M, Weismann T (2006) Effect of 17 $\beta$ estradiol on gamete quality and maturation in two salmonid species. Aquat Toxicol 79:124-131. https://doi.org/10.1016/j.aquatox.2006. 05.011

Leatherland JF (1985) Effects of $17 \beta$-estradiol and methyl testosterone on the activity of the thyroid gland in rainbow trout, Salmo gairdneri Richardson. Gen Comp Endocrinol 60:343-352. https://doi.org/10. 1016/0016-6480(85)90067-X

Leatherland JF (1988) Endocrine factors affecting thyroid economy of teleost fish. Am Zool 28:319-328. https://doi.org/10.1093/icb/28.2. 319

Leatherland JF (1994) Reflections on the thyroidology of fishes: from molecules to humankind. Guelph Ichthyol Rev 2:1-67

Lokman PM, George KA, Divers SL, Algie M, Young G (2007) 11Ketotestosterone and IGF-I increase the size of previtellogenic oocytes from shortfinned eel, Anguilla australis, in vitro. Reproduction 133:955-967. https://doi.org/10.1530/REP-06-0229

Lubzens E, Young G, Bobe J, Cerdà J (2010) Oogenesis in teleosts: how eggs are formed. Gen Comp Endocrinol 165:367-389. https://doi. org/10.1016/j.ygcen.2009.05.022

Maitra AK, Hasan KN (2016) The role of melatonin as a hormone and an antioxidant in the control of fish reproduction. Front Endocrinol 7: 38. https://doi.org/10.3389/fendo.2016.00038

Marlatt VL, Gerrie E, Wiens S, Jackson F, Moon TW, Trudeau VL (2012) Estradiol and triiodothyronine differentially modulate reproductive and thyroidal genes in male goldfish. Fish Physiol. Biochem 38:283-296. https://doi.org/10.1007/s10695-011-9506-z

Maunder RJ, Matthiessen P, Sumpter JP, Pottinger TG (2007) Rapid bioconcentration of steroids in the plasma of three-spined stickleback Gasterosteus aculeatus exposed to waterborne testosterone and 17ß-oestradiol. J Fish Biol 70:678-690. https://doi.org/10. 1111/j.1095-8649.2006.01303.x

Martinović D, Denny JS, Schmieder PK, Ankley GT, Sorensen PW (2008) Temporal variation in the estrogenicity of a sewage treatment plant effluent and its biological significance. Environ Sci Technol 42:3421-3427. https://doi.org/10.1021/es0708013

Martyniuk CJ, Gallant NS, Marlatt VL, Wiens SC, Woodhouse AJ, Trudeau VL (2006) Current perspectives on 17ß-Estradiol (E2) action and nuclear estrogen receptors (ER) in teleost fish. In: Reinecke M, Zaccone G, Kapoor BG (eds) Fish endocrinology, vol 2. Science Publishers, Enfield, pp 625-663. https://doi.org/10.1201/b10745-28

Medda A, Dasmahapatra AK, Ray AK (1980) Effect of estrogen and testosterone on the protein and nucleic acid contents of liver, muscle and gonad and plasma protein content of male and female (vitellogenic and nonvitellogenic) Singi fish, Heteropneustes fossilis Bloch. Gen Comp Endacrinol 42:427-436. https://doi.org/10.1016/ 0016-6480(80)90208-7

Migaud H, Davie A, Martinez Chavez CC, Al-Khamees S (2007) Evidence for differential photic regulation of pineal melatonin synthesis in teleosts. J Pineal Res 43:327-335. https://doi.org/10. 1111/j.1600-079X.2007.00480.x

Miles-Richardson SR, Kramer VJ, Fitzgerald SD, Render JA, Yamini B, Barbee SJ, Giesy JP (1999) Effects of waterborne exposure of 17 $\beta$ estradiol on secondary sex characteristics and gonads of fathead minnows (Pimephales promelas). Aquat Toxicol 47:129-145. https://doi.org/10.1016/S0166-445X(99)00009-0

Mills LJ, Chichester C (2005) Review of evidence: are endocrinedisrupting chemicals in the aquatic environment impacting fish populations? Sci Total Environ 343:1-34. https://doi.org/10.1016/j. scitotenv.2004.12.070

Mori Y, Kano Y (1984) Changes in plasma concentrations of LH, progesterone and oestradiol in relation to the occurrence of luteolysis, oestrus and time of ovulation in the Shiba goat (Capra hircus). $\mathrm{J}$ Reprod Fertil 72:223-230. https://doi.org/10.1530/jrf.0.0720223

National Research Council (1993) Transport and fate of pollutants in the coastal marine environment. In: Managing wastewater in coastal urban areas. The National Academies Press, Washington, D.C., pp 231-294. https://doi.org/10.17226/2049

Nelson ER, Habibi HR (2013) Estrogen receptor function and regulation in fish and other vertebrates. Gen Comp Endocrinol 192:15-24. https://doi.org/10.1016/j.ygcen.2013.03.032

Nelson ER, Habibi HR (2016) Thyroid hormone regulates vitellogenin by inducing estrogen receptor alpha in the goldfish liver. Mol Cell Endocrinol 436:259-267. https://doi.org/10.1016/j.mce.2016.08. 045

Ojaveer H, Galil BS, Lehtiniemi M, Christoffersen M, Clink S, Florin AB, Gruszka P, Puntila R, Behrens JW (2015) Twenty five years of invasion: management of the round goby Neogobius melanostomus in the Baltic Sea. Manag. Biol Invasion 6:329-339. https://doi.org/ 10.3391/mbi.2015.6.4.02

Olivereau M, Olivereau J (1979) Estradiol-positive feedback on gonadotropin $(\mathrm{GtH})$ cells in freshwater male silver eels. Gen Comp Endocrinol 39:247-261. https://doi.org/10.1016/0016-6480(79) 90119-9

Pait AS, Nelson JO (2002) Endocrine disruption in fish: an assessment of recent research and results. NOAA Technical Memorandum NOS NCCOS CCM 149

Panter GH, Thompson RS, Sumpter JP (2000) Intermittent exposure of fish to estradiol. Environ Sci Technol 34:2756-2760. https://doi.org/ 10.1021/es991117u

Pankhurst W, Stacey NE (1985) The effect of $17 \beta$-estradiol on spontaneous ovulation in the goldfish, Carassius auratus. Can J Zool 63: 2979-2981. https://doi.org/10.1139/z85-446

Piferrer F (2001) Endocrine sex control strategies for the feminization of teleost fish. Aquaculture 197:229-281. https://doi.org/10.1016/ S0044-8486(01)00589-0

Plant TM, Zeleznik AJ (2015) Knobil and Neill's physiology of reproduction, 4th edn, vol 1. Elsevier Academic Press, Amsterdam. https://doi.org/10.1016/C2011-1-07288-0

Popek W, Natanek H, Luszczek-Trojnar E (2010) Circadian and seasonal rhythm in secretion of melatonin, dopamine and LH in carp. In: Kulczykowska E, Popek W, Kapoor BG (eds) Biological clock in fish. Science Publishers, Enfield, pp 235-250. https://doi.org/10. 1201/b10170-12

Power DM, Llewellyn L, Faustino M, Nowell MA, Björnsson BT, Einarsdottir IE, Canario AV, Sweeney GE (2001) Thyroid hormones in growth and development of fish. Comp Biochem Physiol C Toxicol Pharmacol 130:447-459. https://doi.org/10. 1016/S1532-0456(01)00271-X

Pusceddu FH, Sugauara LE, Rodrigues de Marchi M, Choueri RB, Castro ÍB (2019) Estrogen levels in surface sediments from a multiimpacted Brazilian estuarine system. Mar Pollut Bull 142:576580. https://doi.org/10.1016/j.marpolbul.2019.03.052

Raine JC (2011) Thyroid hormones and reproduction in fishes. In: Norris DO, Lopez KH (eds) Hormones and reproduction of vertebrates, vol 
1. Fishes, 1st edn. Academic Press, London, pp 83-102. https://doi. org/10.1016/B978-0-12-375009-9.10005-0

Reiter RJ, Rosales-Corral SA, Tan DX, Acuna-Castroviejo D, Qin L, Yang SF, Xu K (2017) Melatonin, a full service anti-cancer agent: inhibition of initiation, progression and metastasis. Int J Mol Sci 18: 843. https://doi.org/10.3390/ijms18040843

Rinchard J, Kestemont P, Kühn ER, Fostier A (1993) Seasonal changes in plasma levels of steroid hormones in an asynchronous fish the gudgeon Gobio gobio L. (Teleostei, Cyprinidae). Gen Comp Endocrinol 92:168-178. https://doi.org/10.1006/gcen.1993.1153

Rocha MJ, Rocha E (2006) Morphofunctional aspects of reproduction from synchronous to asynchronous fishes-an overview. In: Reinecke M, Zaccone G, Kapoor BG (eds) Fish endocrinology, vol 2. Science Publishers, Enfield, pp 571-624. https://doi.org/10. 1201/b10745-27

Rocha MJ, Rocha E (2015) Estrogenic compounds in estuarine and coastal water environments of the Iberian Western Atlantic Coast and selected locations worldwide - relevancy, trends and challenges in view of the EU water framework directive. In: Andreazza AC, Scola G (eds) Toxicology studies-cells, drugs and environment. IntechOpen, London, pp 153-193. https://doi.org/10.5772/59885

Rohr DH, Lokman PM, Davie PS, Young G (2001) 11-Ketotestosterone induces silvering-related changes in immature female short-finned eels, Anguilla australis. Comp Biochem Physiol A Mol Integr Physiol 130:701-714. https://doi.org/10.1016/S1095-6433(01) 00402-0

Sapota MR (2012) NOBANIS - invasive alien species fact sheetNeogobius melanostomus. Online Database of the European Network on Invasive Alien Species-NOBANIS. https://www. nobanis.org/globalassets/speciesinfo/n/neogobius-melanostomus/ neogobius melanostomus.pdf. Accessed 28 September 2019

Schulz RW, de França LR, Lareyre JJ, Le Gac F, Chiarini-Garcia H, Nobrega RH, Miura T (2010) Spermatogenesis in fish. Gen Comp Endocrinol 165:390-411. https://doi.org/10.1016/j.ygcen.2009.02. 013

Singh TP, Raizada RB (1979) Thyroid activity in response to some gonadal steroids in methallibure-treated Heteropneusres fossilis (Bloch). Experientia 35:274-275. https://doi.org/10.1007/ BF01920661

Skóra KE, Stolarski J (1993) New fish species in the Gulf of Gdansk, Neogobius sp. [cf. Neogobius melanostomus (Pallas 1811)]. Bull Sea Fish Inst 1:83-84

Sokołowska E, Kleszczyńska A, Kalamarz-Kubiak H, Arciszewski B, Kulczykowska E (2013) Changes in brain arginine vasotocin, isotocin, plasma 11-ketotestosterone and cortisol in round goby, Neogobius melanostomus, males subjected to overcrowding stress during the breeding season. Comp Biochem Physiol A Mol Integr Physiol 165:237-242. https://doi.org/10.1016/j.cbpa.2013.03.018

Shore LS, Shemesh M (2003) Naturally produced steroid hormones and their release into the environment. Pure Appl Chem 75:1859-1871. https://doi.org/10.1351/pac200375111859

Tarkhani R, Imanpoor MR, Taghizadeh V (2012) Effect of dietary 17ßestradiol on serum sex hormones' levels and gamete quality in goldfish (Carassius auratus). J Comp Clin Path Res 1(3):86-95. https://doi.org/10.5829/idosi.wjfms.2012.04.06.658

Toffol E, Kalleinen N, Haukka J, Vakkuri O, Partonen T, Polo-Kantola P (2014) Melatonin in perimenopausal and postmenopausal women: associations with mood, sleep, climacteric symptoms, and quality of life. Menopause 21:493-500. https://doi.org/10.1097/GME. 0b013e3182a6c8f3

Tollefsen KE (2002) Interaction of estrogen mimics, singly and in combination, with plasma sex steroid-binding proteins in rainbow trout (Oncorhynchus mykiss). Aquat Toxicol 56:215-225. https://doi.org/ 10.1016/S0166-445X(01)00154-0

Trudeau VL, Peter RE, Sloley BD (1991) Testosterone and estradiol potentiate the serum gonadotropin response to gonadotropinreleasing hormone in goldfish. Biol Reprod 44:951-960. https:// doi.org/10.1095/biolreprod44.6.951

Trudeau VL, Wade MG, Van Der Kraak G, Peter RE (1993) Effects of $17 \beta$-estradiol on pituitary and testicular function in male goldfish. Can J Zool 71:1131-1135. https://doi.org/10.1139/z93-154

Vethaak D, Legler J (2012) Endocrine disruption in wildlife: background, effects and implications. In: Matthiessen P (ed) Endocrine disrupters. Hazard testing and assessment methods. Wiley, Hoboken, pp 7-58. https://doi.org/10.1002/9781118355961.ch2

Vos JG, Dybing E, Greim HA, Ladefoged O, Lambré C, Tarazona JV, Brandt I, Vethaak AD (2000) Health effects of endocrine-disrupting chemicals on wildlife, with special reference to the European situation. Crit Rev Toxicol 30:71-133. https://doi.org/10.1080/ 10408440091159176

Yamaguchi S, Gen K, Okuzawa K, Matsuyama M, Kagawa H (2006) Influence of estradiol-17 $\beta$, testosterone, and 11-ketotestosterone on testicular development, serum steroid hormone, and gonadotropin secretion in male red sea bream Pagrus major. Fish Sci 72:835-845. https://doi.org/10.1111/j.1444-2906.2006.01225.x

Yaron Z, Levavi-Sivan B (2011) Endocrine regulation of fish reproduction. In: Farrell AP (ed) Encyclopedia of fish physiology: from genome to environment, vol 2. Gas exchange, internal homeostatis, and food uptake. Academic Press, San Diego, pp 1500-1508. https://doi.org/10.1016/B978-0-12-374553-8.00058-7

Ying G-G, Kookana RS, Ru Y-J (2002) Occurrence and fate of hormone steroids in the environment. Environ Int 28:545-551. https://doi.org/ 10.1016/S0160-4120(02)00075-2

Zeyl JN, Love OP, Higgs DM (2014) Evaluating gonadosomatic index as an estimator of reproductive condition in the invasive round goby, Neogobius melanostomus. J Gt Lakes Res 40:164-171. https://doi. org/10.1016/j.jglr.2013.12.004

Zhang H, Shi J, Liu X, Zhan X, Chen Q (2014) Occurrence and removal of free estrogens, conjugated estrogens, and bisphenol A in manure treatment facilities in East China. Water Res 58:248-257. https:// doi.org/10.1016/j.watres.2014.03.074

Publisher's note Springer Nature remains neutral with regard to jurisdictional claims in published maps and institutional affiliations. 